\title{
Dietary nitrate and population health: a narrative review of the translational potential of existing laboratory studies
}

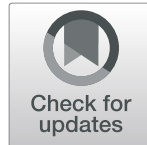

Oliver M. Shannon ${ }^{1}$, Chris Easton², Anthony I. Shepherd ${ }^{3}$, Mario Siervo ${ }^{4}$, Stephen J. Bailey ${ }^{5}$ and Tom Clifford ${ }^{5^{*}}$ (D)

\begin{abstract}
Background: Dietary inorganic nitrate $\left(\mathrm{NO}_{3}{ }^{-}\right)$is a polyatomic ion, which is present in large quantities in green leafy vegetables and beetroot, and has attracted considerable attention in recent years as a potential health-promoting dietary compound. Numerous small, well-controlled laboratory studies have reported beneficial health effects of inorganic $\mathrm{NO}_{3}{ }^{-}$consumption on blood pressure, endothelial function, cerebrovascular blood flow, cognitive function, and exercise performance. Translating the findings from small laboratory studies into 'real-world' applications requires careful consideration.

Main body: This article provides a brief overview of the existing empirical evidence basis for the purported healthpromoting effects of dietary $\mathrm{NO}_{3}{ }^{-}$consumption. Key areas for future research are then proposed to evaluate whether promising findings observed in small animal and human laboratory studies can effectively translate into clinically relevant improvements in population health. These proposals include: 1) conducting large-scale, longer duration trials with hard clinical endpoints (e.g. cardiovascular disease incidence); 2) exploring the feasibility and acceptability of different strategies to facilitate a prolonged increase in dietary $\mathrm{NO}_{3}{ }^{-}$intake; 3 ) exploitation of existing cohort studies to explore associations between $\mathrm{NO}_{3}{ }^{-}$intake and health outcomes, a research approach allowing larger samples sizes and longer duration follow up than is feasible in randomised controlled trials; 4) identifying factors which might account for individual differences in the response to inorganic $\mathrm{NO}_{3}^{-}$(e.g. sex, genetics, habitual diet) and could assist with targeted/personalised nutritional interventions; 5) exploring the influence of oral health and medication on the therapeutic potential of $\mathrm{NO}_{3}{ }^{-}$supplementation; and 6) examining potential risk of adverse events with long term high- $\mathrm{NO}_{3}{ }^{-}$diets.

Conclusion: The salutary effects of dietary $\mathrm{NO}_{3}{ }^{-}$are well established in small, well-controlled laboratory studies. Much less is known about the feasibility and efficacy of long-term dietary $\mathrm{NO}_{3}{ }^{-}$enrichment for promoting health, and the factors which might explain the variable responsiveness to dietary $\mathrm{NO}_{3}{ }^{-}$supplementation between individuals. Future research focussing on the translation of laboratory data will provide valuable insight into the potential applications of dietary $\mathrm{NO}_{3}^{-}$supplementation to improve population health.
\end{abstract}

Keywords: Nitrate, Beetroot juice, Population health, Epidemiology, Randomised controlled trials, Blood pressure, Exercise performance, Translation

\footnotetext{
* Correspondence: T.Clifford@Lboro.ac.uk

${ }^{5}$ School of Sport, Exercise and Health Sciences, Loughborough University, Loughborough, UK

Full list of author information is available at the end of the article
}

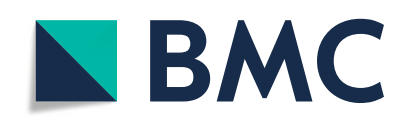

(- The Author(s). 2021 Open Access This article is licensed under a Creative Commons Attribution 4.0 International License, which permits use, sharing, adaptation, distribution and reproduction in any medium or format, as long as you give appropriate credit to the original author(s) and the source, provide a link to the Creative Commons licence, and indicate if changes were made. The images or other third party material in this article are included in the article's Creative Commons licence, unless indicated otherwise in a credit line to the material. If material is not included in the article's Creative Commons licence and your intended use is not permitted by statutory regulation or exceeds the permitted use, you will need to obtain permission directly from the copyright holder. To view a copy of this licence, visit http://creativecommons.org/licenses/by/4.0/. The Creative Commons Public Domain Dedication waiver (http://creativecommons.org/publicdomain/zero/1.0/) applies to the data made available in this article, unless otherwise stated in a credit line to the data. 


\section{Background}

Dietary inorganic nitrate $\left(\mathrm{NO}_{3}{ }^{-}\right)$is a polyatomic ion present in large quantities in green leafy vegetables and certain root vegetables such as beetroot [1]. In recent years, inorganic $\mathrm{NO}_{3}{ }^{-}$has attracted substantial attention as a potential health promoting and exercise performance-enhancing dietary compound. These effects have largely been attributed to its ability to serve as a substrate for the ubiquitous gasotransmitter, nitric oxide (NO; Fig. 1) [2]. Following consumption, inorganic $\mathrm{NO}_{3}{ }^{-}$is absorbed in the upper gastrointestinal tract, increasing plasma $\mathrm{NO}_{3}{ }^{-}$concentration [3]. In the blood, exogenous $\mathrm{NO}_{3}{ }^{-}$mixes with endogenous $\mathrm{NO}_{3}{ }^{-}$produced via oxidation of NO. Most ( 60\%) of the ingested $\mathrm{NO}_{3}{ }^{-}$is excreted in the urine [4]. However, $\sim 25 \%$ is actively taken up by the salivary glands via the transporter protein sialin [5], and secreted into the oral cavity, where it is reduced to nitrite $\left(\mathrm{NO}_{2}^{-}\right)$by facultative anaerobic bacteria residing primarily on the dorsal surface of the tongue $[6,7]$. Salivary (in the saliva) $\mathrm{NO}_{2}{ }^{-}$is then swallowed and a portion is converted into $\mathrm{NO}$ and other nitrogen oxides in the acidic environment of the stomach
$[2,8,9]$. A further portion of the swallowed $\mathrm{NO}_{2}{ }^{-}$ reaches the systemic circulation, where it can be transported to various tissues and reduced to NO by a range of enzymatic and non-enzymatic catalysis [2, 3]. By increasing the bioavailability of $\mathrm{NO}$ and other nitrogen oxides, which play a role in the regulation of multifarious physiological processes, inorganic $\mathrm{NO}_{3}{ }^{-}$has the capacity to elicit far-reaching effects in the human body.

One of the most well-documented effects following inorganic $\mathrm{NO}_{3}{ }^{-}$consumption is a decrease in blood pressure (BP), an effect which was first demonstrated by Larsen and colleagues from the Karolinska Institute in 2006 [10]. This group reported that 3 days of supplementation with $\mathrm{NO}_{3}{ }^{-}$salts $(0.1 \mathrm{mmol} / \mathrm{kg} / \mathrm{d}$ sodium $\mathrm{NO}_{3}{ }^{-}$) reduced diastolic and mean arterial BP by -3.7 and $-3.2 \mathrm{mmHg}$, respectively, in young healthy adults. A number of independent research groups [11-16] has substantiated these promising findings across a range of participant cohorts and using various supplementation strategies, including the provision of whole and juiced vegetables, especially beetroot juice [17]. Over the past 10 years, as this burgeoning research area has expanded,

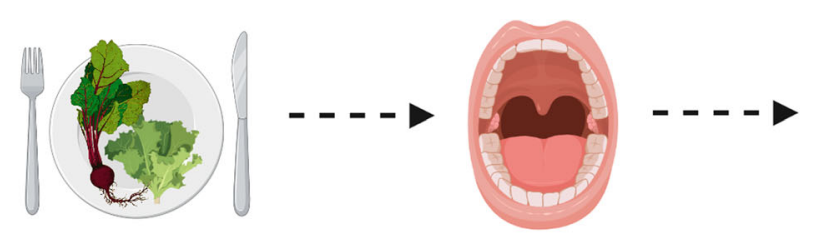

1. Nitrate is readily available in foods such as beetroot and lettuce
2. Swallowed nitrate passes to the stomach and intestines

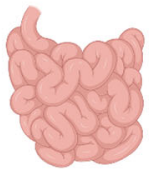

3. Nitrate is almost entirely absorbed in the small intestine

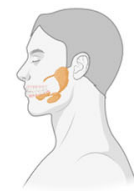

6. Nitrate is also actively transported back into the mouth via sialin in the salivary glands

\section{$5.60 \%$ of nitrate is} excreted in the urine

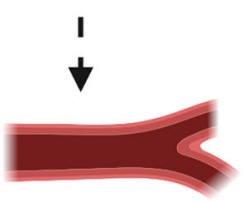

4. Plasma nitrate concentration increases

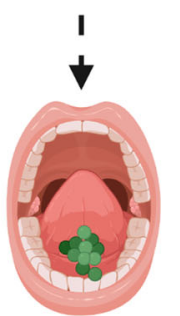

7. Salivary nitrate is reduced to nitrite by bacteria on the tongue

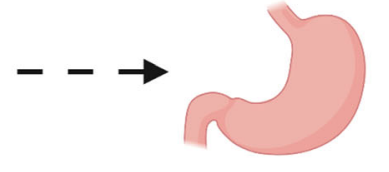

8. In the stomach, some of the swallowed nitrite is reduced to nitric oxide and other reactive nitrogen intermediates

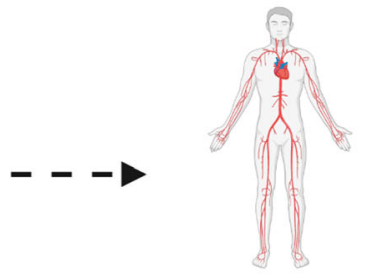

9. A portion of the nitrite enters systemic circulation where it can be further reduced to nitric oxide via nitrite reductases

Fig. 1 A schematic representation of the nitrate-nitrite-nitric oxide pathway. Created with Biorender.com 
various other potentially beneficial effects of inorganic $\mathrm{NO}_{3}{ }^{-}$consumption have also emerged. Notably, $\mathrm{NO}_{3}{ }^{-}$ has been shown to improve a range of cardiovascular risk factors [17], increasing endothelial function [14, 18$21]$, decreasing arterial stiffness [15, 20, 22, 23], and reducing platelet aggregation [20, 24, 25]. Some [26-28], but not all $[18,29-31]$ studies have also shown beneficial effects of inorganic $\mathrm{NO}_{3}{ }^{-}$on cognitive function - effects which may be underpinned by alterations in cerebrovascular blood flow [31-33] and could be of value to a range of clinical and healthy populations [34]. Likewise, $\mathrm{NO}_{3}{ }^{-}$has been identified as a potential prebiotic for the oral microbiome [35], with the potential to positively impact oral health [36]. Moreover, $\mathrm{NO}_{3}{ }^{-}$consumption has been demonstrated to improve performance during continuous [12, 13, 29, 37-42], intermittent [43-45] and strength-based [46, 47] exercise, especially in untrained and recreationally active individuals [40, 48-50]. The mechanisms for the ergogenic effects of $\mathrm{NO}_{3}{ }^{-}$have not been fully resolved, but may include: 1 ) improvements in mitochondrial efficiency (reported by some [51], but not others [52]); 2) enhanced muscle contractile efficiency/ function [53-56]; and 3) augmented tissue blood flow, particularly to areas of low oxygen tensions such as type II muscle fibres (demonstrated in animal models $[57,58]$, but with less convincing data in humans [59-63]).

Current research has provided valuable insight into optimisation of $\mathrm{NO}_{3}{ }^{-}$supplementation strategies (e.g. pharmacokinetics, dose-response and supplementation duration) $[13,64,65]$ and mechanisms of action $[51,53$, $57,66]$. Nevertheless, more research is needed to understand whether findings from typically small, wellcontrolled laboratory studies are likely to translate into clinically relevant improvements in population health. This article highlights key areas for further research that could help in this regard. Such research is warranted to help guide practitioners, influence policy, and form guidelines for the effective and safe consumption of inorganic $\mathrm{NO}_{3}{ }^{-}$.

\section{Main text}

\section{Research focus 1: large-scale, longer duration trials}

Although $\mathrm{NO}_{3}{ }^{-}$consumption has been linked with a range of positive health outcomes, the majority of trials exploring the salutary effects of inorganic $\mathrm{NO}_{3}{ }^{-}$have involved short-term supplementation regimens, typically a few days in duration. Only a handful of trials have explored the medium- to longer-term effects of $\mathrm{NO}_{3}{ }^{-}$consumption (4 weeks to 6 months), usually focusing on BP or endothelial function as an outcome. Whilst not a universal finding $[67,68]$, beneficial effects of medium- to longer-term $\mathrm{NO}_{3}{ }^{-}$supplementation protocols have been reported in some trials [69-71]. For example, Siervo et al. [69] found that 2 months supplementation with $\mathrm{NO}_{3}{ }^{-}$-rich beetroot juice $\left(\sim 6.5 \mathrm{mmol} / \mathrm{d}^{2} \mathrm{NO}_{3}{ }^{-}\right)$decreased 24-h systolic and diastolic BP by -10.8 and $5.4 \mathrm{mmHg}$, respectively, in a Sub-Saharan African setting. Similar effects were also observed when $\mathrm{NO}_{3}{ }^{-}$rich beetroot juice was co-ingested alongside folate. In another study, Mills and colleagues [70] showed that 6 months consumption of $\mathrm{NO}_{3}{ }^{-}$-rich beetroot juice $(\sim 11$ $\mathrm{mmol} / \mathrm{d} \mathrm{NO}_{3}{ }^{-}$) decreased central systolic pressure by $2.6 \mathrm{mmHg}$. Likewise, Kapil et al. [71] reported reductions in 24-h systolic and diastolic BP $(7.7$ and $5.2 \mathrm{mmHg}$, respectively) and improved endothelial function and arterial stiffness with 4 weeks $\mathrm{NO}_{3}{ }^{-}$-rich beetroot juice supplementation $\left(6.4 \mathrm{mmol} / \mathrm{d} \mathrm{NO}_{3}{ }^{-}\right)$with no change after placebo. Although focusing on different outcomes to the above trials, a study by Thompson et al. [72] also showed greater adaptations to sprint interval training in individuals consuming $\mathrm{NO}_{3}{ }^{-}$rich beetroot juice (13 $\mathrm{mmol} / \mathrm{d}$ ) over a 4-week period, providing further evidence of a benefit of this supplement when given over prolonged periods.

By contrast, studies by Blekkenhorst [67] and Sundqvist [68] observed no effects of 4- and 5-week $\mathrm{NO}_{3}{ }^{-}$interventions on BP. The lack of effect in these studies could be related to the relatively low $\mathrm{NO}_{3}{ }^{-}$doses administered (2.4 and $4.8 \mathrm{mmol} / \mathrm{d} \mathrm{NO}_{3}{ }^{-}$, respectively). Conversely, the source of $\mathrm{NO}_{3}{ }^{-}$(vegetables or $\mathrm{NO}_{3}{ }^{-}$pills rather than $\mathrm{NO}_{3}{ }^{-}$-rich beetroot juice) could be relevant in explaining the lack of effect in these studies, given different foods providing equivalent doses of $\mathrm{NO}_{3}{ }^{-}$appear to have divergent effects on plasma $\mathrm{NO}_{2}{ }^{-}$concentration and BP [16], which could be linked to the (poly) phenol and ascorbate content of these foods [73]. Indeed, in most studies to date $\mathrm{NO}_{3}{ }^{-}$has been administered as beetroot juice, which is also rich in a constellation of different bioactive compounds, particularly (poly) phenols and the betalains [74]. Independent of $\mathrm{NO}_{3}{ }^{-}$, betalains have been shown to possess antioxidant [75], antiinflammatory [76], and vasodilatory [77] properties, although studies in humans are still scarce. To isolate the effects $\mathrm{NO}_{3}{ }^{-}$from other compounds in beetroot juice, researchers often compare the effects of a $\mathrm{NO}_{3}{ }^{-}$rich beetroot juice to a taste-, smell- and appearancematched $\mathrm{NO}_{3}{ }^{-}$depleted juice. One limitation of this strategy is that it cannot account for any synergistic interactions between $\mathrm{NO}_{3}{ }^{-}$and the other bioactive compounds that may augment the physiological effects of beetroot juice; in other words, we cannot be certain if the positive effects in these studies are simply due to $\mathrm{NO}_{3}{ }^{-}$or its interactions with the other bioactive compounds present. Thus, studies chiefly aimed at untangling the mechanistic effects of $\mathrm{NO}_{3}{ }^{-}$may prefer to administer $\mathrm{NO}_{3}{ }^{-}$in the form of $\mathrm{NO}_{3}{ }^{-}$salts instead of food-based supplements that contain other compounds. 
Overall, additional comparisons of $\mathrm{NO}_{3}{ }^{-}$rich beetroot juice and sodium $\mathrm{NO}_{2}{ }^{-}$or $\mathrm{NO}_{3}{ }^{-}$supplements are required. When interpreting the findings of the studies discussed in this review, it is important the reader is aware that studies with $\mathrm{NO}_{3}{ }^{-}$salts and $\mathrm{NO}_{3}{ }^{-}$-rich beetroot juice do not contain the same compounds and therefore different effects are possible. Notwithstanding, as discussed in Section 4 of this review, cross-talk between $\mathrm{NO}_{3}{ }^{-}$and other dietary components or participant-level differences in the response to $\mathrm{NO}_{3}{ }^{-}$ could also account for the lack of effect of $\mathrm{NO}_{3}{ }^{-}$in the studies of Blekkenhorst [67] and Sundqvist [68].

Based around the current evidence it is likely that, under the right circumstances (which remain to be fully elucidated), consumption of inorganic $\mathrm{NO}_{3}{ }^{-}$could elicit longer-term health benefits. In order to fully appreciate the potential applications of $\mathrm{NO}_{3}{ }^{-}$on population health, large-scale (e.g. $\mathrm{n}=$ $>1000$ ), longer duration (e.g. $2-5$ years) trials which focus not only on risk factors (e.g. BP, endothelial function, cognitive function), but also incidence of key non-communicable diseases (e.g. CVD, dementia) are warranted. Specific considerations for the design of such studies are provided in Table 1 . Whilst likely to be logistically complex and require substantial financial backing from funders, this research could be justified by the promising evidence from short-term trials and the potential application of findings to ease the unsustainable societal and financial burden of conditions such as CVD (annual global costs $\sim \$ 863$ billion [78]) and dementia (annual global cost $\sim \$ 1$ trillion [79]). Prior to undertaking this research, it is essential to obtain more data on the feasibility and acceptability of different strategies to increase habitual $\mathrm{NO}_{3}{ }^{-}$intake by a sufficient quantity and for a sufficient period to obtain long lasting health benefits. This information is critical for the design of feasible longer-term trials and translation to the general population, and will be explored in more detail in the next section.
Research focus 2: feasibility and acceptability of different strategies to facilitate prolonged, increased consumption of nitrate

To date, a limited number of studies have reported data on the feasibility and acceptability of beetroot juice as a vehicle for increasing habitual $\mathrm{NO}_{3}{ }^{-}$intake. Mixed findings have been reported. For example, Ormesher and colleagues [80] gave 40 pregnant women $70 \mathrm{~mL} / \mathrm{d}$ concentrated beetroot juice $\left(\sim 400 \mathrm{mg}\right.$ of $\left.\mathrm{NO}_{3}{ }^{-}\right)$and, after 8 days of ingestion, $97 \%$ of participants indicated they would consume the supplement again, if they were experiencing benefits. However, only $62 \%$ of participants reported finding it easy to consume the beetroot juice and just over half of the participants rated the drink as palatable (54\%). These findings suggest that longer-term consumption of beetroot juice may be difficult in this cohort, which could impede longer-term adherence. More recently, Kandhari et al. [81] evaluated the feasibility of a 60-day concentrated beetroot juice and folate intervention to treat hypertension in Sub-Saharan Africa. No serious adverse events were reported, and compliance was $>90 \%$, suggesting beetroot juice was well accepted in this population. In addition, all participants rated the taste as "good" or "very good" and most participants $(\sim 87 \%)$ indicated a preference for beetroot juice over BP medication. The studies by Ormesher et al. [80] and Kandhari et al. [81] both administered the same brand of concentrated beetroot juice, such that the different findings cannot be attributed to a different type of supplement administered. Alternatively, it is possible that the different findings of Ormesher et al. [80], which was conducted in the UK, and Kandhari et al. [81], which was conducted in Tanzania, reflect cultural/ regional differences in food preference. However, it is noteworthy that participants in the Ormesher et al. [80] study were also pregnant, which may have further

Table 1 Key considerations for future randomised controlled trials exploring the health effects of $\mathrm{NO}_{3}{ }^{-}$ingestion

\begin{tabular}{|c|c|}
\hline Consideration & Recommendation \\
\hline Dose & Consumption of a $\mathrm{NO}_{3}{ }^{-}$dose $\geq 8 \mathrm{mmol}$ \\
\hline $\mathrm{NO}_{3}^{-}$form & Provision of $\mathrm{NO}_{3}^{-}$salts or vegetables, with $\mathrm{NO}_{3}^{-}$content independently verified \\
\hline Study duration & Longer duration (e.g., months-to-years) warranted \\
\hline Participant cohort & 'At risk' cohort studied (e.g., individuals with hypertension for studies exploring effects of $\mathrm{NO}_{3}{ }^{-}$on cardiovascular disease risk) \\
\hline $\begin{array}{l}\text { Genetics/ } \\
\text { microbiome }\end{array}$ & Consider recruitment of T allele carriers with G894T polymorphism in the eNOS gene \\
\hline Microbiome & Consider recruitment of individuals with greater abundance of $\mathrm{NO}_{3}{ }^{-}$reducing oral bacteria \\
\hline Mouthwash & Avoidance of mouthwash prior to and during the study \\
\hline Dietary controls & Avoidance of thiocyanate and sulphate rich foods in conjunction with $\mathrm{NO}_{3}^{-}$ \\
\hline $\begin{array}{l}\text { Other lifestyle } \\
\text { factors }\end{array}$ & Avoidance of smoking \\
\hline Outcomes & $\begin{array}{l}\text { Inclusion of hard clinical endpoints (e.g., CVD or dementia incidence) to build upon promising findings on risk factors for these } \\
\text { conditions }\end{array}$ \\
\hline
\end{tabular}


contributed towards the difference in palatability given pregnancy is known to influence taste [82].

In another study, Babateen et al. [83] examined the feasibility of different doses of concentrated beetroot juice in overweight and obese older adults over a 13week period. Compliance was high, no adverse events were reported, and the attrition rate was $19 \%$, which is similar or lower than the dropout rates reported in other human intervention trials [84, 85]. Collectively, these studies suggest that beetroot juice may represent an acceptable strategy to facilitate increased consumption of $\mathrm{NO}_{3}{ }^{-}$, at least in certain cohorts. However, future studies need to evaluate the feasibility and acceptability of beetroot juice consumption over longer periods (e.g., $>6$ months) and in other populations.

Concentrated, commercially available beetroot juice shots have the advantage of being readily available (they are now sold in many major supermarket chains) and contain a standardised dose of $\mathrm{NO}_{3}{ }^{-}$sufficient to influence myriad health outcomes. This form of beetroot juice has also been shown to be more effective at reducing BP (and presumably eliciting other physiological changes) than non-concentrated beetroot juice when the same dose is administered [86]. In addition, as mentioned in the previous section, beetroot juice also contains other bioactive compounds that may contribute to overall health. Nevertheless, as participants do not always enjoy the taste of beetroot juice and the relatively high cost of commercially available beetroot 'shots' ( $£ 1-2$ or $\$ 2-3$ each) may be prohibitive to some users, it is essential for researchers to explore the feasibility and acceptability of other strategies to increase $\mathrm{NO}_{3}{ }^{-}$consumption. This could include other $\mathrm{NO}_{3}{ }^{-}$-rich foods (e.g. lettuce, rhubarb, spinach, radish), gels, powders, crystals, capsules and non-beetroot drinks. To this end, both Blekkenhorst et al. [67] (>98\% compliance) and Sundqvist et al. [68] (>97\% compliance) demonstrated excellent compliance to 4 and 5 week interventions, respectively, with $\mathrm{NO}_{3}{ }^{-}$-rich vegetables, which were well tolerated with minimal side effects. Importantly, Sundqvist et al. [68] reported similar compliance between $\mathrm{NO}_{3}{ }^{-}$-rich vegetables and $\mathrm{NO}_{3}{ }^{-}$-containing pills $(>97 \%$ vs. $>98 \%$ ). Nevertheless, neither Blekkenhorst et al. [67] nor Sundqvist et al. [68] reported beneficial physiological effects of their interventions, which could be related to the relatively modest $\mathrm{NO}_{3}{ }^{-}$doses provided $(\sim 2.4$ and $4.8 \mathrm{mmol} / \mathrm{d}$ respectively) or other methodological factors which were discussed in Section 1 of this review. A comprehensive investigation of patient preferences and the real and perceived barriers of adopting a high- $\mathrm{NO}_{3}{ }^{-}$diet or consuming $\mathrm{NO}_{3}{ }^{-}$-rich supplements warrants further investigation. In addition, studies need to determine the amount of $\mathrm{NO}_{3}{ }^{-}$-rich vegetables required to elicit beneficial physiological effects, whether this is achievable for different populations, and whether effects are superior to non-vegetable $\mathrm{NO}_{3}{ }^{-}$sources. Finally, it is worth exploring whether there are regional and population preferences, as this knowledge could be used to develop more targeted $\mathrm{NO}_{3}{ }^{-}$products.

\section{Research focus 3: nitrate intake and health outcomes in epidemiological studies}

The role of dietary $\mathrm{NO}_{3}{ }^{-}$for human health has gradually shifted over the last five decades. Indeed, this compound was initially considered as a risk factor for cancer, endocrine disorders and infant methaemoglobinaemia. However, the stigma attached to dietary $\mathrm{NO}_{3}{ }^{-}$has gradually dwindled, and $\mathrm{NO}_{3}{ }^{-}$is now viewed by many a potential health-promoting compound (see Section 6 for further details). The initial results suggesting a harmful role of dietary $\mathrm{NO}_{3}{ }^{-}$intake (from food) were mostly derived from animal models and weakly designed epidemiological studies which have had a prominent, almost demonizing, influence on defining the role of dietary $\mathrm{NO}_{3}{ }^{-}$ for human health [87]. These initial studies informed the still contentious WHO nutritional recommendations for dietary $\mathrm{NO}_{3}{ }^{-}$intake in humans which was set at $3.7 \mathrm{mg} /$ $\mathrm{kg}$ body weight [88]. The perception of dietary $\mathrm{NO}_{3}{ }^{-}$as a risk factor started to change with the discovery of the role of $\mathrm{NO}_{3}{ }^{-}$as key substrate for the $\mathrm{NO}_{3}{ }^{-} \mathrm{NO}_{2}{ }^{-} \mathrm{-NO}$ pathway and the evidence of a beneficial effect of $\mathrm{NO}_{3}{ }^{-}$ on health parameters such as BP.

After the study by Larsen et al. [10] in 2006, which first demonstrated a BP lowering effect of sodium $\mathrm{NO}_{3}{ }^{-}$, there was a rapid surge in research testing the effects of dietary $\mathrm{NO}_{3}{ }^{-}$on health outcomes [89]. However, the research strategy in the last decade has almost taken an inverse approach to that typically adopted in nutritional science as the conduction of clinical trials have surpassed epidemiological investigations, which are generally considered as a first step to validate research hypotheses [90-92]. One of the primary reasons for the inverse trend is the lack of reliable and representative food databases of $\mathrm{NO}_{3}{ }^{-}$content to support an accurate dietary assessment [93]. An additional limitation is the severe lack of validation studies testing the accuracy of dietary assessment methods against valid biomarkers of $\mathrm{NO}_{3}{ }^{-}$intake (e.g. 24-h urinary $\mathrm{NO}_{3}{ }^{-}$concentrations) [94]. This is compounded by the fact that the $\mathrm{NO}_{3}{ }^{-}$content of vegetables will vary by farming method (whether $\mathrm{NO}_{3}{ }^{-}$fertiliser is used or not), growing conditions, time of year the crop is harvested, and storage conditions [1], such that there is likely to be a degree of error in estimated $\mathrm{NO}_{3}{ }^{-}$intake values [95]. Several research groups have developed independent databases by collecting data on $\mathrm{NO}_{3}{ }^{-}$food content from published sources in an attempt to obtain valid estimates of $\mathrm{NO}_{3}{ }^{-}$intake and evaluate associations with health outcomes [96, 97]. 
Although this is a step in the right direction, it remains difficult to accurately estimate long-term habitual dietary $\mathrm{NO}_{3}{ }^{-}$intake for the reasons mentioned above. In addition, $\mathrm{NO}_{3}{ }^{-}$concentrations measured in biological fluids have been used in some analysis as indirect markers of $\mathrm{NO}_{3}{ }^{-}$intake [98]. Whether these objective markers of $\mathrm{NO}_{3}{ }^{-}$intake show stronger links with health outcomes compared with subjective, self-reported $\mathrm{NO}_{3}{ }^{-}$ intake values, is the subject of ongoing research. A summary of the key non-cancer related epidemiological studies testing the association of inorganic $\mathrm{NO}_{3}{ }^{-}$with health outcomes is provided in Table 2 .

The first studies to evaluate the association between dietary $\mathrm{NO}_{3}{ }^{-}$intake and health outcomes were conducted in 2016 in Iran (two studies) $[99,101]$ and in the United States (one study) [100]. The former evaluated the association of vegetable $\mathrm{NO}_{3}{ }^{-}$intake with risk of chronic kidney disease in the Tehran Lipid and Glucose Study and found a higher prevalence of chronic kidney disease (CKD) at baseline (cross-sectional analysis) in the high- $\mathrm{NO}_{3}{ }^{-}$intake group whereas no significant association with CKD risk was observed after a 3-year follow up [101]. Using the same dataset, Bahadoran et al. [99] found that dietary $\mathrm{NO}_{3}{ }^{-}$intake, overall and from animal sources, was not associated with prospective risk of diabetes. The US study was conducted in a very large sample (>100,000 participants) and assessed dietary $\mathrm{NO}_{3}{ }^{-}$intake in the Nurses' Health Study and the Health Professionals Follow-up Study [100]. The results showed a significantly lower risk of primary open-angle glaucoma in participants with higher $\mathrm{NO}_{3}{ }^{-}$intake [100]. However, a subsequent analysis conducted in the Nurses' Health Study found a non-significant association between dietary $\mathrm{NO}_{3}{ }^{-}$and prospective risk of coronary heart disease [111]. More recently, several crosssectional and longitudinal studies have observed significant associations between high $\mathrm{NO}_{3}{ }^{-}$intake or urinary $\mathrm{NO}_{3}{ }^{-}$concentrations (as a proxy for $\mathrm{NO}_{3}{ }^{-}$intake) with cardiovascular outcomes including lower BP [107], risk of hypertension [109], common carotid intimal medial thickness [103], congestive heart failure [114] and CVD mortality [109]. Conversely, higher plasma $\mathrm{NO}_{3}{ }^{-}$concentrations in the Framingham Offspring Study [106] were associated with an increased risk of all-cause mortality, which may be explained by the rise in plasma $\mathrm{NO}_{3}{ }^{-}$concentrations in participants with impaired kidney function included in the analysis and highlights the potential risk of reverse causality in these investigations. The improvements in physical performance and cognition observed in some of the $\mathrm{NO}_{3}{ }^{-}$supplementation trials were also explored in two cross sectional studies [98, 112]. Improved hand-grip strength and timed up and go tests (a test of functional mobility) were observed in middle-aged and older Australian participants with a higher $\mathrm{NO}_{3}{ }^{-}$intake [112] whereas $\mathrm{NO}_{3}{ }^{-}$concentrations measured in spot urine samples were not associated with improved cognition in 1015 older Americans participants enrolled in the National Health and Nutrition Examination Survey [98]. The NIH workshop on dietary $\mathrm{NO}_{3}{ }^{-}$held in 2016 [115] advocated for more epidemiological research to be conducted to better define the predictive role of dietary $\mathrm{NO}_{3}{ }^{-}$consumption for the prevention as well as treatment of chronic diseases. The consensus statement also encouraged the development of detailed and country-specific $\mathrm{NO}_{3}{ }^{-}$food composition tables for a more accurate assessment of the exposure to dietary $\mathrm{NO}_{3}{ }^{-}$[115]. The current epidemiological evidence points towards a protective role of dietary $\mathrm{NO}_{3}{ }^{-}$ intake for cardiovascular events and mortality whereas the predictive role for cancer risk is still undefined as latest meta-analyses on the topic indicate a lack of association between dietary $\mathrm{NO}_{3}{ }^{-}$consumption and cancer risk [116, 117]. There is still scarce or no data from prospective studies on the association of dietary $\mathrm{NO}_{3}{ }^{-}$intake with other chronic conditions with established links with $\mathrm{NO}_{3}{ }^{-} / \mathrm{NO}_{2}{ }^{-}$and $\mathrm{NO}$ pathways such as diabetes, hypertension, physical disability or dementia. Further epidemiological studies in this area are therefore warranted. Such research will complement the findings from RCTs, by providing information on the effectiveness of a $\mathrm{NO}_{3}{ }^{-}$for disease reduction in real-world circumstances with greater sample sizes and longer follow up than is logistically feasible in most RCTs [90, 91].

\section{Research focus 4: inter-individual differences in the response to nitrate}

At the individual participant level, several groups have suggested the existence of possible 'responders' and 'non-responders' to $\mathrm{NO}_{3}{ }^{-}$, irrespective of the vehicle used to provide this inorganic anion [64, 118, 119]. It is important to note that random within-subject variation could explain much of the variability in response to $\mathrm{NO}_{3}{ }^{-}$supplementation between individuals [120, 121]. Similarly, issues may also arise when attempting to establish whether an individual is a dependable 'responder' or 'non-responder' on different occasions [122, 123]. Nevertheless, several factors have been identified which could explain genuine differences in the response to $\mathrm{NO}_{3}{ }^{-}$between individuals. These include individual characteristics such as age [124, 125], health [126] and exercise training status [40, 49], sex [14], genetic factors [127], and differences in the oral microbiome (explored further in Section 5 of this review). In addition, betweenparticipant differences in potentially plastic lifestyle factors such as smoking status [128], use of mouthwash [129], and habitual diet $[49,130]$ might also impact an individual's response to $\mathrm{NO}_{3}{ }^{-}$. We briefly review the impact of these variables on the effects of $\mathrm{NO}_{3}{ }^{-}$below. 
Table 2 Key epidemiological studies exploring associations between inorganic nitrate consumption and non-cancer related health outcomes

\begin{tabular}{|c|c|c|c|c|c|c|}
\hline $\begin{array}{l}\text { Author, } \\
\text { year }\end{array}$ & $\begin{array}{l}\text { Population } \\
\text { Size }\end{array}$ & Study Design & $\begin{array}{l}\text { Duration } \\
\text { of Follow } \\
\text { up }(y)\end{array}$ & $\begin{array}{l}\text { Nitrate } \\
\text { Assessment }\end{array}$ & Health Outcome & Key Findings \\
\hline $\begin{array}{l}\text { Bahadoran } \\
\text { et al., [99] }\end{array}$ & 4920 & $\begin{array}{l}\text { Prospective } \\
\text { (Tehran Lipid } \\
\text { and Glucose } \\
\text { Study) }\end{array}$ & 5.8 & FFQ & Type 2 Diabetes (T2D) & $\begin{array}{l}\text { No significant association between } \\
\mathrm{NO}_{3}{ }^{-} \text {intake and the risk of } \mathrm{T} 2 \mathrm{D} \text { in fully } \\
\text { adjusted model }\end{array}$ \\
\hline $\begin{array}{l}\text { Kang et al. } \\
{[100]}\end{array}$ & $\begin{array}{l}\text { Nurses' } \\
\text { Health Study } \\
(63,893 \\
\text { women) } \\
\text { Health } \\
\text { Professionals } \\
\text { Follow-up } \\
\text { Study (41,094 } \\
\text { men) }\end{array}$ & Prospective & $\begin{array}{l}\sim 30 \text { years } \\
\text { for both }\end{array}$ & FFQ & $\begin{array}{l}\text { Primary open-angle glau- } \\
\text { coma (POAG) }\end{array}$ & $\begin{array}{l}\text { Higher dietary } \mathrm{NO}_{3}^{-} \text {and green leafy } \\
\text { vegetable intake was associated with a } \\
\text { lower POAG risk, particularly POAG } \\
\text { with early paracentral VF loss at } \\
\text { diagnosis. }\end{array}$ \\
\hline $\begin{array}{l}\text { Mirmiran } \\
\text { et al. [101] }\end{array}$ & 1546 & $\begin{array}{l}\text { Prospective } \\
\text { (Tehran Lipid } \\
\text { and Glucose } \\
\text { Study) }\end{array}$ & 3 & FFQ & Chronic Kidney Disease (CKD) & $\begin{array}{l}\text { At baseline, higher intake of high- } \\
\text { vegetable } \mathrm{NO}_{3}^{-} \text {intake was associated } \\
\text { with a } 48 \% \text { higher chance of having }^{-} \text {CKD (OR } 1.48,95 \% \mathrm{Cl} 1.05-2.13 \text { ). After } \\
3 \text { years of follow-up, there was no sig- } \\
\text { nificant association with the occur- } \\
\text { rence of CKD }\end{array}$ \\
\hline $\begin{array}{l}\text { Blekkenhorst } \\
\text { et al. [102] }\end{array}$ & 1227 & $\begin{array}{l}\text { Prospective } \\
\text { (Perth } \\
\text { Longitudinal } \\
\text { Study of Aging } \\
\text { in Women) }\end{array}$ & 15 & FFQ & $\begin{array}{l}\text { Atherosclerotic vascular } \\
\text { disease (ASVD) mortality }\end{array}$ & $\begin{array}{l}\text { A high vegetable } \mathrm{NO}_{3}{ }^{-} \text {intake was } \\
\text { associated with a lower risk of ASVD } \\
\text { (HR: } 0.7995 \% \mathrm{Cl}: 0.68,0.93, P=0.004) \\
\text { and all-cause mortality (HR: } 0.8795 \% \\
\text { Cl: } 0.78,0.97, P=0.011 \text { ) }\end{array}$ \\
\hline $\begin{array}{l}\text { Bondonno } \\
\text { et al. [103] }\end{array}$ & 1226 & $\begin{array}{l}\text { Prospective } \\
\text { (Perth } \\
\text { Longitudinal } \\
\text { Study of Aging } \\
\text { in Women) }\end{array}$ & 14.5 & FFQ & $\begin{array}{l}\text { CCA-IMT, plaque severity and } \\
\text { risk of an ischemic } \\
\text { cerebrovascular disease } \\
\text { event }\end{array}$ & $\begin{array}{l}\text { Higher intake of vegetable } \mathrm{NO}_{3}{ }^{-} \text {was } \\
\text { associated with } 17 \% \text { lower risk of } \\
\text { cerebrovascular disease events }(P= \\
0.02) \text { and lower CCA-IMT }(P=0.002) \text {. }\end{array}$ \\
\hline $\begin{array}{l}\text { Gumanova } \\
\text { et al. [104] }\end{array}$ & 1087 & $\begin{array}{l}\text { Cross-sectional } \\
\text { (Stress Aging and } \\
\text { Health Study) }\end{array}$ & - & Plasma NOx & $\begin{array}{l}\text { Diabetes type II, } \\
\text { hyperthyroidism, coronary } \\
\text { heart disease, gout and } \\
\text { thrombosis/stroke, } \\
\text { osteoporosis, cancer }\end{array}$ & $\begin{array}{l}\mathrm{NOx} \text { over } 44.7 \mu \mathrm{M} \text { were associated with } \\
\text { increased prevalence of diabetes type } \\
\text { II, hyperthyroidism, coronary heart } \\
\text { disease, gout and thrombosis/stroke }\end{array}$ \\
\hline $\begin{array}{l}\text { Kuhnle et al. } \\
\text { [105] }\end{array}$ & 7598 & $\begin{array}{l}\text { Cross-sectional } \\
\text { (EPIC Norfolk) }\end{array}$ & - & $\begin{array}{l}\text { Drinking water } \\
\mathrm{NO}_{3}^{-} \\
\text {concentrations }\end{array}$ & Blood pressure (BP) & $\begin{array}{l}\text { At low sulfate concentrations, } \mathrm{NO}_{3}^{-} \\
\text {was inversely associated with } \mathrm{BP}(-4 \\
\mathrm{mmHg} \text { in top quintile) whereas this } \\
\text { was reversed at higher concentrations } \\
(+3 \mathrm{mmHg} \text { in top quintile) }\end{array}$ \\
\hline $\begin{array}{l}\text { Maas et al. } \\
{[106]}\end{array}$ & 2855 & $\begin{array}{l}\text { Prospective } \\
\text { (Framingham } \\
\text { Offspring Study) }\end{array}$ & 17.3 & Plasma $\mathrm{NO}_{3}^{-}$ & $\begin{array}{l}\text { All-cause mortality and } \\
\text { incident CVD }\end{array}$ & $\begin{array}{l}\text { Plasma } \mathrm{NO}_{3}{ }^{-} \text {was weakly associated } \\
\text { with an increased risk of death ( } \mathrm{HR}, \\
1.16 ; 95 \% \mathrm{Cl}, 1.00-1.35 P=0.057) \text { but } \\
\text { not with incident } \mathrm{CVD}\end{array}$ \\
\hline $\begin{array}{l}\text { Smallwood } \\
\text { et al. [107] }\end{array}$ & 919 & $\begin{array}{l}\text { Cross-Sectional } \\
\text { (InChianti) }\end{array}$ & - & $\begin{array}{l}\text { 24-h urinary } \\
\mathrm{NO}_{3}^{-}\end{array}$ & Blood pressure & $\begin{array}{l}\text { Systolic blood pressure in the } \geq 2 \mathrm{mmol} \\
\text { urinary } \mathrm{NO}_{3}^{-} \text {excretion group was } 3.9 \\
(\mathrm{Cl}:-7.1 \text { to }-0.7) \mathrm{mm} \text { Hg lower than } \\
\text { in the comparison }<1 \mathrm{mmol} \text { excretion } \\
\text { group. }\end{array}$ \\
\hline $\begin{array}{l}\text { Liu et al. } \\
\text { [108] }\end{array}$ & 2900 & $\begin{array}{l}\text { Prospective (Blue } \\
\text { Mountains Eye } \\
\text { Study) }\end{array}$ & 15 & FFQ & CVD mortality & $\begin{array}{l}\text { In multivariable-adjusted analysis, par- } \\
\text { ticipants in quartile } 4 \text { [ }>137.8 \mathrm{mg} / \mathrm{d} \text {; } \\
\mathrm{HR} 0.63(95 \% \mathrm{Cl} 0.41,0.95) \text { ] of vege- } \\
\text { table } \mathrm{NO}_{3}{ }^{-} \text {intake had lower hazards } \\
\text { for } \mathrm{CVD} \text { mortality compared to partici- } \\
\text { pants in quartile } 1(<69.5 \mathrm{mg} / \mathrm{d})\end{array}$ \\
\hline
\end{tabular}


Table 2 Key epidemiological studies exploring associations between inorganic nitrate consumption and non-cancer related health outcomes (Continued)

\begin{tabular}{|c|c|c|c|c|c|c|}
\hline $\begin{array}{l}\text { Author, } \\
\text { year }\end{array}$ & $\begin{array}{l}\text { Population } \\
\text { Size }\end{array}$ & Study Design & $\begin{array}{l}\text { Duration } \\
\text { of Follow } \\
\text { up (y) }\end{array}$ & $\begin{array}{l}\text { Nitrate } \\
\text { Assessment }\end{array}$ & Health Outcome & Key Findings \\
\hline $\begin{array}{l}\text { Mendy et al. } \\
\text { [109] }\end{array}$ & 17,618 & $\begin{array}{l}\text { Prospective } \\
\text { (NHANES) }\end{array}$ & 4.3 & $\begin{array}{l}\text { Urinary } \mathrm{NO}_{3}^{-} \\
\text {in spot urine } \\
\text { samples }\end{array}$ & $\begin{array}{l}\text { Hypertension and CVD } \\
\text { prevalence and all-cause } \\
\text { mortality }\end{array}$ & $\begin{array}{l}\text { 1-unit increase in log-transformed urin- } \\
\text { ary } \mathrm{NO}_{3}^{-} \text {was associated with a }>30 \% \\
\text { decrease in the odds of hypertension } \\
\text { (odds ratio, } 0.67 ; 95 \% \text { confidence inter- } \\
\text { val }[\mathrm{Cl}], 0.55-0.81) \text {, stroke }(\mathrm{OR}, 0.61,95 \% \\
\mathrm{Cl}, 0.43-0.87) \text { and cardiovascular mor- } \\
\text { tality }(\mathrm{HR}, 0.44 ; 95 \% \mathrm{Cl}, 0.26-0.73 \text { ) }\end{array}$ \\
\hline $\begin{array}{l}\text { Jackson et al. } \\
\text { [110] }\end{array}$ & 5324 & $\begin{array}{l}\text { Prospective } \\
\text { (Australian } \\
\text { Longitudinal } \\
\text { Study on } \\
\text { Women's Health) }\end{array}$ & 15 & FFQ & $\begin{array}{l}\text { Incidence of self-reported } \\
\text { CVD-related complications }\end{array}$ & $\begin{array}{l}\text { Women reporting higher total dietary } \\
\mathrm{NO}_{3}{ }^{-} \text {intakes }(\mathrm{Q} 4>78.2 \mathrm{mg} / \mathrm{d}) \text { and } \\
\text { vegetable } \mathrm{NO}_{3}^{-} \text {intakes }(\mathrm{Q} 4>64.4 \mathrm{mg} / \\
\text { d) were } 25 \text { and } 27 \% \text { reduced risk of } \\
\text { developing CVD-related complications, } \\
\text { respectively. }\end{array}$ \\
\hline $\begin{array}{l}\text { Jackson et al. } \\
\text { [111] }\end{array}$ & $\begin{array}{l}\text { Nurses' } \\
\text { Health Study } \\
\text { and Health } \\
(62,535 \\
\text { women })\end{array}$ & Prospective & 26 & FFQ & Coronary heart disease & $\begin{array}{l}\text { Dietary } \mathrm{NO}_{3}{ }^{-} \text {intake was not related to } \\
\text { risk of } \mathrm{CHD} \text { after adjustment for other } \\
\text { lifestyle and non-vegetable dietary } \\
\text { factors }\end{array}$ \\
\hline $\begin{array}{l}\text { Sim et al. } \\
\text { [112] }\end{array}$ & 1420 & $\begin{array}{l}\text { Cross-sectional } \\
\text { (Perth } \\
\text { Longitudinal } \\
\text { Study of Aging } \\
\text { in Women) }\end{array}$ & - & FFQ & $\begin{array}{l}\text { Hand-grip strength and time } \\
\text { up and go (TUG) }\end{array}$ & $\begin{array}{l}\text { Higher } \mathrm{NO}_{3}{ }^{-} \text {intake }(31.2 \mathrm{mg} / \mathrm{d}) \text { was } \\
\text { associated with lower odds for weak } \\
\text { grip strength (OR 0.84, } 95 \% \mathrm{Cl} 0.74- \\
0.95, P=0.005) \text { and slow TUG (OR 0.86, } \\
95 \% \mathrm{Cl} 0.76-0.98, P=0.021)\end{array}$ \\
\hline $\begin{array}{l}\text { Riddell et al. } \\
\text { [113] }\end{array}$ & 2656 & Prospective & 1.5 & $\begin{array}{l}\text { Urinary } \\
\mathrm{NO}_{3}^{-} \text {to } \\
\text { creatinine } \\
\text { ratio (UNCR) }\end{array}$ & $\begin{array}{l}\text { Prediction of renal transplant } \\
\text { rejection }\end{array}$ & $\begin{array}{l}\text { Overall UNCR was highly variable with } \\
\text { no diagnostic threshold for kidney } \\
\text { transplant rejection }\end{array}$ \\
\hline $\begin{array}{l}\text { Wu et al. } \\
\text { [114] } 2020\end{array}$ & 14,894 & $\begin{array}{l}\text { Cross-sectional } \\
\text { (NHANES) }\end{array}$ & - & $\begin{array}{l}\text { Urinary } \mathrm{NO}_{3}^{-} \\
\text {in spot urine } \\
\text { samples }\end{array}$ & $\begin{array}{l}\text { Congestive heart failure, } \\
\text { coronary heart disease, } \\
\text { angina pectoris, myocardial } \\
\text { infarction }\end{array}$ & $\begin{array}{l}\text { Significant association between urinary } \\
\mathrm{NO}_{3}{ }^{-} \text {and congestive heart failure } \\
(\mathrm{OR}=0.651,95 \% \mathrm{Cl} 0.507-0.838, P< \\
0.001)\end{array}$ \\
\hline $\begin{array}{l}\text { Pereira et al. } \\
\text { [98] }\end{array}$ & 1015 & $\begin{array}{l}\text { Cross-sectional } \\
\text { (NHANES) }\end{array}$ & - & $\begin{array}{l}\text { Urinary } \mathrm{NO}_{3}^{-} \\
\text {in spot urine } \\
\text { samples }\end{array}$ & Cognitive function & $\begin{array}{l}\text { Urinary } \mathrm{NO}_{3}{ }^{-} \text {concentrations were not } \\
\text { associated with cognitive performance } \\
\text { on any of the cognitive tests. }\end{array}$ \\
\hline
\end{tabular}

EPIC European Prospective Investigation of Cancer, FFQ Food Frequency Questionnaire, CCA-IMT Common Carotid Intimal Medial Thickness, $\mathrm{NO}_{3}{ }^{-} \mathrm{Nitrate}, \mathrm{NO}_{2}{ }^{-}$ nitrite, NOx Nitrate + Nitrite Concentration, CVD Cardiovascular Disease, OR Odds Ratio, HR Hazard Ratio, NHANES National Health and Nutrition Examination Survey, uNCR Urinary nitrate to creatinine ratio

Individuals with lower aerobic fitness levels may respond more favourably to $\mathrm{NO}_{3}{ }^{-}$supplementation [40, 131]. This theory stemmed from several studies reporting that while $\mathrm{NO}_{3}{ }^{-}$supplementation from any source enhanced exercise performance in recreational level athletes $\left(\mathrm{V}^{2 \text { peak }}\right.$ 40-60 $\mathrm{ml} / \mathrm{kg} / \mathrm{min}$ ), such effects were less pronounced or nonexistent in well-trained and elite endurance athletes (typically manifesting a $\dot{\mathrm{VO}}_{2 \max }>60 \mathrm{ml} / \mathrm{kg} / \mathrm{min}$ ) [132-135]. Porcelli et al. [40] provide the most convincing evidence to support this notion and demonstrated that, when all other methodological factors such as the exercise test and $\mathrm{NO}_{3}{ }^{-}$dose are held content, individuals with a higher aerobic fitness status are less responsive to the ergogenic effects of $\mathrm{NO}_{3}{ }^{-}$. Indeed, those authors reported beneficial effects of sodium $\mathrm{NO}_{3}{ }^{-}$on $3 \mathrm{~km}$ running performance in individuals with low $\left(\mathrm{V}^{2} \mathrm{O}_{2 \text { peak }}\right.$ : $28.2-44.1 \mathrm{ml} / \mathrm{kg} / \mathrm{min})$, and moderate $\left(\mathrm{V}^{2 \text { peak }}\right.$ : $45.5-57.1 \mathrm{ml} /$ $\mathrm{kg} / \mathrm{min})$, but not high $\left(\mathrm{V}_{2 \text { peak }}: 63.9-81.1 \mathrm{ml} / \mathrm{kg} / \mathrm{min}\right)$ aerobic fitness levels. Several possible explanations have been put forth to try and explain why high fitness levels might render $\mathrm{NO}_{3}{ }^{-}$supplementation less effective, and these are discussed in detail elsewhere [40, 131, 136]. One prominent explanation is that elite endurance athletes might produce more NO via the canonical NOS pathways and are therefore less reliant on $\mathrm{NO}_{3}{ }^{-}$as a substrate for $\mathrm{NO}$ generation [132]. Furthermore, recent evidence indicates that $\mathrm{NO}_{3}{ }^{-}$might elicit preferential effects on type II compared with type I muscle fibres [54, 57, 58]. Well-trained endurance athletes might therefore benefit less from $\mathrm{NO}_{3}{ }^{-}$supplementation given a lower proportion of type II, and a higher proportion of type I, muscle fibres compared with recreationally active individuals [137, 138]. In contrast, some studies have shown a beneficial effect of $\mathrm{NO}_{3}{ }^{-}$in well-trained athletes [42, 139141]. Jonvik et al., (2015) suggested that methodological limitations of some studies could at least partly explain the null findings in some studies with elite athletes. Notably, there are far less studies assessing the effects of $\mathrm{NO}_{3}{ }^{-}$ 
supplementation, irrespective of vehicle, in well-trained athletes in comparison to healthy, physically active, individuals. This is likely because well-trained athletes are only a small fraction of the population, and are logistically harder to test and recruit to studies due to their desire to avoid potential training interruptions. Thus, more research is still required to ascertain the influence of aerobic fitness levels on the responsiveness to $\mathrm{NO}_{3}{ }^{-}$supplementation.

Women are underrepresented in research into the health effects of dietary $\mathrm{NO}_{3}{ }^{-}$[142]. Nevertheless, preliminary evidence suggests potentially differential effects of $\mathrm{NO}_{3}{ }^{-}$(at least in regard to the effects of $\mathrm{NO}_{3}{ }^{-}$on $\mathrm{BP}$ ) between the sexes, which warrants further investigation. Women have been demonstrated to have greater oral $\mathrm{NO}_{3}{ }^{-}$reducing capacity than men due to an oral microflora composition that is more conducive for $\mathrm{NO}_{3}{ }^{-}$reduction to $\mathrm{NO}_{2}{ }^{-}$[143]. Nevertheless, Kapil et al. [14] and Coles and Clifton [144] both demonstrated BPlowering effects of $\mathrm{NO}_{3}{ }^{-}$(potassium $\mathrm{NO}_{3}{ }^{-}$and beetroot juice, respectively) in men with higher baseline $\mathrm{BP}$ and lower plasma $\mathrm{NO}_{2}{ }^{-}$concentrations but not in women. Likewise, in a meta-analysis by Jackson et al. [17], BP reductions with $\mathrm{NO}_{3}{ }^{-}$were greater in studies with more male participants. Those authors speculated that this could be related to a greater vascular production of NO in pre-menopausal women due to oestrogen-related release and activity of $\mathrm{NO}$ [145], diminishing the response to supplemental $\mathrm{NO}_{3}{ }^{-}$in women compared with men.

Although studies remain scarce, there is some evidence that the heterogeneous responses to $\mathrm{NO}_{3}{ }^{-}$supplementation are partly explained by polymorphisms in the eNOS gene. This was first explored by Hobbs et al., [127], who examined the effects of $\mathrm{NO}_{3}{ }^{-}$supplementation on BP in patients with and without a specific polymorphism in the eNOS gene (G894T), which has been suggested to inhibit NO production from eNOS [127]. Although findings are equivocal [146], the G894T polymorphism, alongside being a $\mathrm{T}$ allele carrier, has been associated with cardiovascular disease [147-149], of which a key risk factor is diminished NO bioavailability [150, 151]. Intriguingly, despite the small sample size $(n=14)$, Hobbs et al., [127] found that $\mathrm{NO}_{3}{ }^{-}$supplementation (beetroot bread) only reduced BP in patients who were both $\mathrm{T}$ allele carriers and had the G894T polymorphism in the eNOS gene. A more recent study examined the influence of the G894T polymorphism and $\mathrm{NO}_{3}{ }^{-}$therapy on mortality in chronic heart failure patients [146]. Somewhat at odds with the findings of Hobbs et al., [127], Azzam et al. [146] found that $\mathrm{NO}_{3}{ }^{-}$ therapy (source not specified) increased the risk of mortality in patients with the G894T polymorphism, and to a greater extent in $G$ allele carriers, suggesting that $\mathrm{NO}_{3}{ }^{-}$therapy might increase mortality in advanced heart failure. However, as this study was observational, cause-effect relationships cannot be established. Moreover, the findings are at contrast to the beneficial effects of $\mathrm{NO}_{3}{ }^{-}$shown in most [152-155], but not all [156, 157], short term intervention trials which show that $\mathrm{NO}_{3}{ }^{-}$improves cardiac function and/or exercise capacity in heart failure patients. Clearly, more studies with larger cohorts are required to determine the extent to which genetic variation influences the responsiveness to $\mathrm{NO}_{3}{ }^{-}$ supplementation, but the findings from these two studies raise the possibility that that genetic factors could contribute towards the inter-individual variability reported by many studies.

Smoking has been shown to increase plasma and salivary concentrations of thiocyanate [158], a compound which competitively inhibits uptake of $\mathrm{NO}_{3}{ }^{-}$into the salivary glands [159], potentially reducing the amount of 'substrate' available to the oral bacteria for reduction into $\mathrm{NO}_{2}{ }^{-}$. Consequently, it is possible that smokers will experience compromised $\mathrm{NO}_{3}{ }^{-}$metabolism and thus a diminished physiological response to $\mathrm{NO}_{3}{ }^{-}$supplementation versus non-smokers. Indeed, Bailey et al. [128] demonstrated a smaller increase in salivary $\mathrm{NO}_{3}{ }^{-}$, plasma $\mathrm{NO}_{3}{ }^{-}$and $\mathrm{NO}_{2}{ }^{-}$concentration, and an attenuated $\mathrm{BP}$ response, following a $\mathrm{NO}_{3}^{-}$bolus (beetroot juice) in smokers compared to non-smoking controls.

It is possible that supplemental $\mathrm{NO}_{3}{ }^{-}$is ineffective at eliciting meaningful physiological changes in individuals habitually consuming a high $\mathrm{NO}_{3}{ }^{-}$diet. Nevertheless, as population intake of $\mathrm{NO}_{3}{ }^{-}$is typically low - Babateen et al. [93] reported a median intake of $108 \mathrm{mg} / \mathrm{d}$ in healthy individuals. With very few individuals regularly consuming $\mathrm{NO}_{3}^{-}$levels to match those provided through supplementation [160], high habitual $\mathrm{NO}_{3}{ }^{-}$intake is unlikely to explain a lack of response to $\mathrm{NO}_{3}{ }^{-}$ supplementation in most 'non-responders'. Alternatively, there is compelling evidence to suggest that consumption of other dietary compounds alongside $\mathrm{NO}_{3}{ }^{-}$may have the capacity to influence response to this compound, such that an individual's background diet could determine (at least transiently) their status as a $\mathrm{NO}_{3}{ }^{-}$ 'responder' or 'non-responder'. For example, consumption of glucosinolate-rich vegetables, such as those from the Brassica family like broccoli, cauliflower, and cabbage, proximal to consumption of $\mathrm{NO}_{3}{ }^{-}$-rich vegetables was shown to blunt the BP lowering response of the latter [130]. Interestingly, this appears to be related to a similar mechanism to which smoking attenuates the effect of $\mathrm{NO}_{3}{ }^{-}$. Specifically, during processes that result in plant cell membrane damage such as mastication, glucosinolates are exposed to the enzyme myrosinase, which catalyses the hydrolysis of glucosinolates into thiocyanate [161]. Although consumption of thiocyanate-rich vegetables leads to lower salivary and plasma thiocyanate concentrations compared with smoking, Dewhurst-Trigg 
et al. [130] showed that the BP-lowering effect of a $\mathrm{NO}_{3}{ }^{-}$-rich smoothie was attenuated by the presence of thiocyanate rich vegetables. In that study, thiocyanate did not seem to interfere with $\mathrm{NO}_{3}{ }^{-}$transport into the mouth (as evident by similar salivary $\mathrm{NO}_{3}{ }^{-}$concentrations when $\mathrm{NO}_{3}{ }^{-}$was consumed alongside vegetables that were both high and low in thiocyanate), suggesting that thiocyanate may influence other aspects of $\mathrm{NO}_{3}{ }^{-}$ metabolism. Specifically, co-ingestion of thiocyanate synthesising vegetables and $\mathrm{NO}_{3}{ }^{-}$-rich vegetables lowered salivary $\mathrm{NO}_{2}^{-}$concentration compared to ingestion of $\mathrm{NO}_{3}{ }^{-}$-rich vegetables alone. This suggests that some Brassica vegetables might transiently alter the oral microbiome, consistent with the antimicrobial effects of thiocyanate derivatives in the oral cavity [162].

A study by Hughan et al. [163] found that the coingestion of sodium $\mathrm{NO}_{3}{ }^{-}$alongside conjugated linoleic acid, an unsaturated fatty acid particularly abundant in dairy and meat products, attenuated the rise in plasma $\mathrm{NO}_{3}{ }^{-}$and $\mathrm{NO}_{2}{ }^{-}$concentrations and supressed the BPlowering and platelet-inhibiting effects that were apparent when supplements were administered in isolation. Mechanistically, co-consumption of conjugated linoleic acid altered the metabolic fate of ingested $\mathrm{NO}_{3}{ }^{-}$leading to the formation of conjugated linoleic acid nitration products, which do not appear to have the same vasodilatory and platelet inhibiting properties as $\mathrm{NO}_{2}{ }^{-}$and NO. Likewise, Bailey et al. [164] found that the ingestion of iodide, which is fortified in many foods [165] and known to compete for salivary $\mathrm{NO}_{3}{ }^{-}$uptake [159], lowered salivary $\mathrm{NO}_{3}{ }^{-}$concentration when co ingested with $\mathrm{NO}_{3}{ }^{-}$rich beetroot juice. However, the increase in salivary and plasma $\mathrm{NO}_{2}{ }^{-}$concentration, alongside the lowering of $\mathrm{BP}$, were similar compared with $\mathrm{NO}_{3}{ }^{-}$alone. Finally, a possible interaction between dietary $\mathrm{NO}_{3}{ }^{-}$and sulphate was identified by Kuhnle et al. [105] who indicated that when estimated sulphate intake was low, higher dietary $\mathrm{NO}_{3}{ }^{-}$intake was associated with lower BP. Conversely, when sulphate intake was high, this association was reversed, such that greater $\mathrm{NO}_{3}{ }^{-}$intake was actually associated with higher BP. The mechanistic basis through which sulphate could modulate the BP lowering effects of dietary $\mathrm{NO}_{3}{ }^{-}$is presently unknown.

Collectively, the evidence presented above indicates that the response to $\mathrm{NO}_{3}{ }^{-}$is unlikely to be uniform between individuals, and could also potentially differ within individuals based around malleable lifestyle factors such as habitual diet. Better understanding the factors that influence responsiveness to $\mathrm{NO}_{3}{ }^{-}$is crucial to maximise the efficacy of $\mathrm{NO}_{3}{ }^{-}$-based interventions and will facilitate the development of targeted interventions for individuals most likely to benefit from consumption of this compound. Given many of the factors which appear to moderate the effectiveness of $\mathrm{NO}_{3}{ }^{-}$impact the oral conversion of this compound into $\mathrm{NO}_{2}{ }^{-}$, future research could also explore the potential physiological effects of direct $\mathrm{NO}_{2}{ }^{-}$administration (for a recent example, see [166]), which does not require processing in the mouth and could theoretically elicit more consistent responses between individuals. Nevertheless, caution should be taken to ensure such a strategy does not increase formation of potentially carcenogenic nitrosamines [167].

\section{Research focus 5: oral microbiota and oral health}

Once in the oral cavity, $\mathrm{NO}_{3}{ }^{-}$is reduced to $\mathrm{NO}_{2}{ }^{-}$during the anaerobic respiration of facultative and obligate bacteria which are particularly abundant on the dorsal surface of the tongue [168]. The oral microbiome collectively comprises over 700 individual species or phylotypes of bacteria that are organised in a series of complex interdependent communities [169]. To date, 14 species of bacteria have been identified as $\mathrm{NO}_{3}{ }^{-}$reducers, the majority of which are from the genera Veillonella, Prevotella, Neisseria, and Haemophilus [170]. A greater relative abundance of these bacteria on the tongue has been shown to augment the rate and magnitude of salivary $\mathrm{NO}_{2}{ }^{-}$production following the ingestion of $\mathrm{NO}_{3}{ }^{-}$rich beetroot juice [171]. Conversely, disruption of the oral microbiome by antibacterial mouthwash causes a transient loss of viable $\mathrm{NO}_{3}{ }^{-}$-reducing bacteria [172] and severely blunts the generation of $\mathrm{NO}_{2}{ }^{-}$in the saliva [173]. Strong antibacterial mouthwash has also been shown to increase BP, likely due to suppression of $\mathrm{NO}$ production from the $\mathrm{NO}_{3}{ }^{-}-\mathrm{NO}_{2}{ }^{-} \mathrm{NO}$ pathway [174-176]. These data confirm the essential role of the oral bacteria in NO homeostasis and support the hypothesis that oral and systemic health are inextricably linked [177].

The mouth is continually exposed to the external environment and is regularly subjected to brushing, flossing, and nutrient intake, all of which may influence the physiological conditions inside the oral cavity and alter the composition of the bacterial milieu [178]. Ageing is known to cause a reduction in salivary flow rate [179] and has been reported to alter the composition of the oral microbiome in some [180, 181] but not all [182] studies. Other factors may also be expected to influence the abundance and activity of oral bacteria, including exercise, diet, oral and systemic diseases, haemodialysis [183] and peritoneal dialysis [184] and medication (particularly antibiotics). In particular, the ingestion of $\mathrm{NO}_{3}{ }^{-}$-rich beetroot juice has been shown to increase salivary $\mathrm{pH}$ and cause meaningful alterations to the oral microbiome in favour of oral health [182, 185]. Given the multitude of potential modifiers, it is perhaps unsurprising that there is profound between-individual variation in the abundance of $\mathrm{NO}_{3}{ }^{-}$-reducing bacteria [121] 
Of note, these authors also reported significant withinindividual week-to-week variability in the abundance of these bacteria and the magnitude by which plasma $\mathrm{NO}_{2}{ }^{-}$ increased following the ingestion of $\mathrm{NO}_{3}{ }^{-}$-rich beetroot juice. This was despite participants standardising their diet, physical activity, use of mouthwash, teeth brushing, and tongue cleaning between visits. The unpredictability in how different individuals respond to $\mathrm{NO}_{3}{ }^{-}$supplementation and how the same individual responds across repeated visits poses a particular challenge for researchers who wish to explore the therapeutic effects of this dietary intervention.

While recent advancements in genomic sequencing techniques have greatly enhanced our understanding of human bacterial interactions in the context of $\mathrm{NO}$ homeostasis, several important questions remain unanswered. To date, the majority of the research exploring links between the oral microbiome and health outcomes has only reported the relative abundance of phyla, genera, or species. Although this quantifies the proportional makeup of the community structure it does not reveal the metabolic activities of individual bacterial species [186] which may vary depending on substrate availability, metabolite expression from neighbouring microbes and host cells, and the impact of environmental conditions [187]. Future research should deploy meta-transcriptomic analysis to determine how factors such as diet, medication, physical activity, ageing, and disease influence $\mathrm{NO}_{2}{ }^{-}$and $\mathrm{NO}_{3}{ }^{-}$reductase gene expression of the oral bacteria. Furthermore, data from epidemiological studies and short-term intervention trials seem to support the notion that increasing habitual dietary intake of $\mathrm{NO}_{3}{ }^{-}$can improve markers of oral health and reduce the incidence of caries [185, 188, 189]. It remains to be established whether dietary $\mathrm{NO}_{3}{ }^{-}$supplementation may also be an effective treatment method for those already suffering from oral diseases such as chronic periodontitis.

\section{Research focus 6: risks versus rewards}

$\mathrm{NO}_{3}{ }^{-}$is increasingly recognised as a beneficial ion that protects against chronic disease, yet, as noted in Section 3 of this review, historically, it was considered a food contaminant with adverse health effects, particularly increased risk of certain cancers and methaemoglobinaemia $[1,88]$. While the aforementioned WHO ADI for $\mathrm{NO}_{3}{ }^{-}$of $3.7 \mathrm{mg} / \mathrm{kg}$ of body mass remain in place today, the discovery of multiple positive health effects of $\mathrm{NO}_{3}{ }^{-}$ have prompted a re-examination of these claims.

In 2004 the WHO reaffirmed their restrictions on $\mathrm{NO}_{3}{ }^{-}$intake yet, in 2008, a panel of experts from the European Food Safety Authority, concluded that the epidemiological evidence did not support an association between $\mathrm{NO}_{3}{ }^{-}$and cancer risk [190]. Similarly, in 2010, the International Agency for Research on Cancer confirmed that there was inadequate evidence to suggest $\mathrm{NO}_{3}{ }^{-}$from food or water was carcinogenic in humans [191]. Evidence that $\mathrm{NO}_{3}{ }^{-}$might cause infant methemoglobinemia, which was first mooted in the 1940s [192], has also been questioned. Indeed, an investigation conducted on behalf of the WHO in 2004 found no exposure-response relationship between dietary $\mathrm{NO}_{3}{ }^{-}$and methemoglobinemia in infants [193]. It is also worth noting that although some studies report mild adverse symptoms with high $\mathrm{NO}_{3}{ }^{-}$intake such as nausea and sickness, to the authors knowledge, no serious adverse events have ever been reported in clinical trials administering $\mathrm{NO}_{3}{ }^{-}[1,93]$.

Notwithstanding, the available evidence does not rule out the possibility that prolonged consumption of $\mathrm{NO}_{3}{ }^{-}$ above the ADI could harm health. Currently, at least with short to medium term intakes, research suggests that doses exceeding the ADI are needed to optimise vascular health or exercise performance $[17,48]$. Because most human trials have only examined the acute health effects $(<4$ weeks $)$ of increased $\mathrm{NO}_{3}{ }^{-}$intake, the longterm safety of consuming $\mathrm{NO}_{3}{ }^{-}$in amounts that exceed the ADI is not well understood. At present, epidemiological studies provide the strongest evidence that prolonged, high intakes of $\mathrm{NO}_{3}{ }^{-}$are safe. Indeed, these indicate that rather than being harmful, dietary $\mathrm{NO}_{3}{ }^{-}$intake is inversely associated with cardiovascular disease risk [102, 194] and certain cancers [117]. Furthermore, diets and dietary patterns high in fruits and vegetables are linked to greater longevity $[195,196]$, protection against type 2 diabetes [197] and chronic obstructive pulmonary disease [198], and improved cardiovascular [92, 199, 200] and cognitive health [201, 202]. This suggests that higher intake of dietary $\mathrm{NO}_{3}{ }^{-}$, at least through plants, is more likely to be associated with health benefits than adverse effects.

Some animal studies have explored the longer-term effects of high dietary $\mathrm{NO}_{3}{ }^{-}$intake on health. In a study in rats, 10 weeks of a low sodium $\mathrm{NO}_{3}{ }^{-}$dose $(0.1 \mathrm{mmol} / \mathrm{kg} /$ d), which the authors suggest is equivalent to amounts achievable in the human diet, reduced $\mathrm{BP}$, whereas a much higher dose $(1 \mathrm{mmol} / \mathrm{kg} / \mathrm{d})$, elevated BP [203]. Interestingly, this study found that the high $\mathrm{NO}_{3}{ }^{-}$dose down-regulated eNOS activity, not only suggesting a crosstalk between the canonical and $\mathrm{NO}_{3}{ }^{-}-\mathrm{NO}_{2}{ }^{-}-\mathrm{NO}$ pathway, but also that any vascular benefits afforded by $\mathrm{NO}_{3}{ }^{-}$supplementation could wane over time. Nonetheless, these findings were not supported by a more recent animal study from the same group. Hezel and colleagues [204] fed mice the human equivalent of $350 \mathrm{mg} / \mathrm{d}$ or 26 $\mathrm{mg} / \mathrm{d}$ of sodium $\mathrm{NO}_{3}{ }^{-}$. After 17 months, mice consuming the high $\mathrm{NO}_{3}{ }^{-}$diet did not have elevated $\mathrm{BP}$ or any other adverse health effects, despite the fact the dose 
exceeded the WHO recommended ADI for an adult under $\sim 95 \mathrm{~kg}$. On the contrary, the high $\mathrm{NO}_{3}{ }^{-}$diet decreased plasma insulin and modulated inflammation, findings consistent with the metabolic benefits observed in acute human studies [205]. These effects need to be verified in humans but support the notion that prolonged increases in $\mathrm{NO}_{3}{ }^{-}$intake are not harmful to health.

It is important to note that any carcinogenic risk attributed to $\mathrm{NO}_{3}{ }^{-}$intake could be mitigated by the intake of antioxidants such as vitamin C or (poly) phenols, which are present in most fruits and vegetables. Studies have shown that vitamin $\mathrm{C}$ and $\mathrm{E}$ are effective inhibitors of nitrosamine formation [167]. In addition, (poly) phenols, which are abundant in commonly consumed $\mathrm{NO}_{3}{ }^{-}$ sources such as spinach and beetroot [206], can also abrogate nitrosamine formation [73]. Thus, increasing $\mathrm{NO}_{3}{ }^{-}$intake through a greater vegetable intake may significantly lessen the risk of any $\mathrm{NO}_{3}{ }^{-}$induced nitrosamine formation. This could partly explain why diets high in vegetables are associated with a reduced and not heightened risk of cancer.

Health concerns have also been raised over the high oxalate content of $\mathrm{NO}_{3}{ }^{-}$-rich vegetables [207, 208]. Oxalates are present in several foods, but particularly high in spinach, beetroot, and rhubarb [208, 209]. Intake of these foods increases urinary oxalate excretion, a risk factor for renal stone formation [209-211], thus, it is currently recommended that foods rich in dietary oxalates are consumed in moderation [208, 210]. However, the link between dietary oxalates and kidney stone formation remains equivocal. Although consuming oxalate rich foods increases oxalate excretion, a large prospective study (>190,000 participants) found only modest non-significant associations between dietary oxalate intake and kidney stone risk, concluding that dietary oxalate intake is not a major risk factor for the formation of kidney stones in younger or older adults [212]. Furthermore, the Dietary Approaches to Stop Hypertension (DASH) diet, which is high in oxalates and $\mathrm{NO}_{3}{ }^{-}$-rich vegetables [1], was recently shown to increase urinary oxalate excretion but reduce the risk of kidney stone formation in $\sim 260$ patients [213]. The authors attributed these findings to the high calcium and magnesium content of the diet limiting oxalate absorption. This is supported by previous research showing that oxalates from beetroot have low bioavailability $(<1 \%)$, owing to their high calcium content [209]. While more prospective human trials are needed, evidence that oxalate rich vegetables increase the risk of kidney stone formation is limited.

To summarise, claims that dietary $\mathrm{NO}_{3}{ }^{-}$promotes cancer or methemoglobinemia, or that dietary oxalates cause kidney stones are weak and unsubstantiated.
Rather, there is compelling evidence that dietary $\mathrm{NO}_{3}{ }^{-}$ has salutary health effects and warrants consideration as a long-term therapeutic treatment strategy to manage vascular and metabolic health. Notwithstanding, longerterm studies in humans are lacking and thus it cannot be ruled out that a prolonged increase in $\mathrm{NO}_{3}{ }^{-}$intake, above the WHO recommended ADI, may have adverse effects for some individuals. Thus, it is incumbent that researchers examine the long-term safety of increasing dietary $\mathrm{NO}_{3}{ }^{-}$consumption in a range of contexts and populations. This research will be vital for convincing the public and regulators that $\mathrm{NO}_{3}{ }^{-}$consumption is safe and that current recommendations to limit dietary $\mathrm{NO}_{3}{ }^{-}$ intake should be re-considered.

\section{Conclusions}

This article has briefly outlined the current state of knowledge around the potential health effects of dietary inorganic $\mathrm{NO}_{3}{ }^{-}$. Six key areas worthy of future research were identified to enhance understanding of the potential role of $\mathrm{NO}_{3}^{-}$in improving population health. As such, it is hoped that this article will help direct researchers to further explore the role of $\mathrm{NO}_{3}{ }^{-}$as a potential health-promoting dietary component.

\section{Abbreviations \\ ADI: Acceptable daily intake; BP: Blood pressure; CVD: Cardiovascular disease; CKD: Chronic kidney disease; DASH: Dietary approach to stop hypertension; eNOS: Endothelial nitric oxide synthase; NIH: National Institutes of Health; $\mathrm{NO}_{3}{ }^{-}$: Nitrate; $\mathrm{NO}$ : Nitric oxide; $\mathrm{NO}_{2}{ }^{-}$: Nitrite; $\mathrm{VO}_{2 \text { peak: }}$ Peak oxygen uptake; WHO: World Health Organisation}

\section{Acknowledgements}

Not applicable.

Authors' contributions

This review was conceived by OMS and TC, and designed by OMS, CE, AIS, MS, SJB and TC. OMS, CE, AIS, MS, SJB and TC drafted and critically revised the manuscript. OMS created the schematic. All authors approved the final version of the manuscript prior to submission.

Funding

No specific funding was received to support the writing of this review.

Availability of data and materials

Not applicable.

\section{Declarations}

Ethics approval and consent to participate

Not applicable.

Consent for publication

Not applicable.

\section{Competing interests}

T.C is an Associate Editor for BMC Sport Science, Medicine \& Rehabilitation. All other authors declare no conflict of interest.

\section{Author details}

'Human Nutrition Research Centre, Population Health Sciences Institute, Newcastle University, Newcastle upon Tyne, UK. ${ }^{2}$ Institute for Clinical Exercise and Health Science, University of the West of Scotland, Blantyre, Scotland, UK. ${ }^{3}$ School of Sport, Health \& Exercise Science, University of Portsmouth, 
Portsmouth, UK. ${ }^{4}$ School of Life Sciences, The University of Nottingham Medical School, Queen's Medical Centre, Nottingham, UK. ${ }^{5}$ School of Sport, Exercise and Health Sciences, Loughborough University, Loughborough, UK.

Received: 24 February 2021 Accepted: 26 May 2021

Published online: 07 June 2021

\section{References}

1. Hord NG, Tang Y, Bryan NS. Food sources of nitrates and nitrites: the physiologic context for potential health benefits. Am J Clin Nutr. 2009;90:110.

2. Kapil V, Khambata RS, Jones DA, Rathod K, Primus C, Massimo G, et al. The noncanonical pathway for in vivo nitric oxide generation: the nitrate-nitritenitric oxide pathway. Pharmacol Rev. 2020;72:692-766.

3. Lundberg JO, Weitzberg E, Gladwin MT. The nitrate-nitrite-nitric oxide pathway in physiology and therapeutics. Nat Rev Drug Discov. 2008;7:156-67.

4. Lundberg JO, Govoni M. Inorganic nitrate is a possible source for systemic generation of nitric oxide. Free Radic Biol Med. 2004;37:395-400.

5. Qin L, Liu X, Sun Q, Fan Z, Xia D, Ding G, et al. Sialin (SLC17A5) functions as a nitrate transporter in the plasma membrane. Proc Natl Acad Sci U S A. 2012;109:13434-9.

6. Duncan C, Dougall H, Johnston P, Green S, Brogan R, Leifert C, et al. Chemical generation of nitric oxide in the mouth from the enterosalivary circulation of dietary nitrate. Nat Med. 1995;1:546-51.

7. Hezel M, Weitzberg E. The oral microbiome and nitric oxide homoeostasis. Oral Dis. 2015;21:7-16.

8. Lundberg JO, Weitzberg E, Lundberg JM, Alving K. Intragastric nitric oxide production in humans: measurements in expelled air. Gut. 1994:35:1543-6.

9. Benjamin N, O'Driscoll F, Dougall H, Duncan C, Smith L, Golden M, et al. Stomach NO synthesis. Nature. 1994;368:502.

10. Larsen FJ, Ekblom B, Sahlin K, Lundberg JO, Weitzberg E. Effects of dietary nitrate on blood pressure in healthy volunteers. N Engl J Med. 2006;355: 2792-3.

11. Webb AJ, Patel N, Loukogeorgakis S, Okorie M, Aboud Z, Misra S, et al. Acute blood pressure lowering, vasoprotective and anti-platelet properties of dietary nitrate via bioconversion to nitrite. Hypertension. 2008;51:784-90.

12. Bailey SJ, Winyard P, Vanhatalo A, Blackwell JR, DiMenna FJ, Wilkerson DP, et al. Dietary nitrate supplementation reduces the $\mathrm{O} 2$ cost of low-intensity exercise and enhances tolerance to high-intensity exercise in humans. J Appl Physiol. 2009;107:1144-55.

13. Vanhatalo A, Bailey SJ, Blackwell JR, DiMenna FJ, Pavey TG, Wilkerson DP, et al. Acute and chronic effects of dietary nitrate supplementation on blood pressure and the physiological responses to moderate-intensity and incremental exercise. Am J Physiol Regul Integr Comp Physiol. 2010;299: R1121-31.

14. Kapil V, Milsom AB, Okorie M, Maleki-Toyserkani S, Akram F, Rehman F, et al. Inorganic nitrate supplementation lowers blood pressure in humans: role for nitrite-derived NO. Hypertension. 2010;56:274-81.

15. Ashor AW, Shannon OM, Werner A-D, Scialo F, Gilliard CN, Cassel KS, et al. Effects of inorganic nitrate and vitamin C co-supplementation on blood pressure and vascular function in younger and older healthy adults: a randomised double-blind crossover trial. Clin Nutr. 2020;39:708-17.

16. Jonvik KL, Nyakayiru J, Pinckaers PJ, Senden JM, van Loon LJ, Verdijk LB. Nitrate-rich vegetables increase plasma nitrate and nitrite concentrations and lower blood pressure in healthy adults. J Nutr. 2016;146:986-93.

17. Jackson JK, Patterson AJ, MacDonald-Wicks LK, Oldmeadow C, McEvoy MA. The role of inorganic nitrate and nitrite in cardiovascular disease risk factors: a systematic review and meta-analysis of human evidence. Nutr Rev. 2018: 76:348-71.

18. Bondonno CP, Downey LA, Croft KD, Scholey A, Stough C, Yang X, et al. The acute effect of flavonoid-rich apples and nitrate-rich spinach on cognitive performance and mood in healthy men and women. Food Funct. 2014;5: 849.

19. Heiss C, Meyer C, Totzeck M, Hendgen-Cotta UB, Heinen $Y$, Luedike $P$, et al. Dietary inorganic nitrate mobilizes circulating angiogenic cells. Free Radic Biol Med. 2012;52:1767-72.

20. Velmurugan S, Gan JM, Rathod KS, Khambata RS, Ghosh SM, Hartley A, et al. Dietary nitrate improves vascular function in patients with hypercholesterolemia: a randomized, double-blind, placebo-controlled study. Am J Clin Nutr. 2016;103:25-38.
21. Shepherd Al, Costello JT, Bailey SJ, Bishop N, Wadley AJ, Young-Min S, et al. "Beet" the cold: beetroot juice supplementation improves peripheral blood flow, endothelial function, and anti-inflammatory status in individuals with Raynaud's phenomenon. J Appl Physiol. 2019;127:1478-90.

22. Bahra M, Kapil V, Pearl V, Ghosh S, Ahluwalia A. Inorganic nitrate ingestion improves vascular compliance but does not alter flow-mediated dilatation in healthy volunteers. Nitric Oxide. 2012;26:197-202.

23. Kim J-K, Moore DJ, Maurer DG, Kim-Shapiro DB, Basu S, Flanagan MP, et al. Acute dietary nitrate supplementation does not augment submaximal forearm exercise hyperemia in healthy young men. Appl Physiol Nutr Metab. 2015;40:122-8.

24. Velmurugan S, Kapil V, Ghosh SM, Davies S, McKnight A, Aboud Z, et al. Antiplatelet effects of dietary nitrate in healthy volunteers: involvement of cGMP and influence of sex. Free Radic Biol Med. 2013;65:1521-32.

25. Richardson G, Hicks SL, O'Byrne S, Frost MT, Moore K, Benjamin N, et al. The ingestion of inorganic nitrate increases gastric S-nitrosothiol levels and inhibits platelet function in humans. Nitric Oxide. 2002;7:24-9.

26. Gilchrist M, Winyard PG, Fulford J, Anning C, Shore AC, Benjamin N. Dietary nitrate supplementation improves reaction time in type 2 diabetes: development and application of a novel nitrate-depleted beetroot juice placebo. Nitric Oxide. 2014:40:67-74.

27. Wightman EL, Haskell-Ramsay CF, Thompson KG, Blackwell JR, Winyard PG, Forster J, et al. Dietary nitrate modulates cerebral blood flow parameters and cognitive performance in humans: a double-blind, placebo-controlled, crossover investigation. Physiol Behav. 2015;149:149-58.

28. Thompson C, Wylie L, Fulford J, Kelly J, Black MI, McDonagh STJ, et al. Dietary nitrate improves sprint performance and cognitive function during prolonged intermittent exercise. Eur J Appl Physiol. 2015. https://doi.org/1 0.1007/s00421-015-3166-0.

29. Shannon OM, Duckworth L, Barlow MJ, Deighton K, Matu J, Williams EL, et al. Effects of dietary nitrate supplementation on physiological responses, cognitive function, and exercise performance at moderate and very-high simulated altitude. Front Physiol. 2017;8:401.

30. Kelly J, Fulford J, Vanhatalo A, Blackwell JR, French O, Bailey SJ, et al. Effects of short-term dietary nitrate supplementation on blood pressure, $\mathrm{O} 2$ uptake kinetics, and muscle and cognitive function in older adults. Am J Physiol Regul Integr Comp Physiol. 2013;304:R73-83.

31. Thompson KG, Turner L, Prichard J, Dodd F, Kennedy DO, Haskell C, et al. Influence of dietary nitrate supplementation on physiological and cognitive responses to incremental cycle exercise. Respir Physiol Neurobiol. 2014;193: $11-20$.

32. Aamand R, Dalsgaard T, Ho Y-CL, Møller A, Roepstorff A, Lund TE. A NO way to BOLD?: dietary nitrate alters the hemodynamic response to visual stimulation. Neurolmage. 2013;83:397-407.

33. Presley TD, Morgan AR, Bechtold E, Clodfelter W, Dove RW, Jennings JM, et al. Acute effect of a high nitrate diet on brain perfusion in older adults. Nitric Oxide. 2011:24:34-42.

34. Clifford T, Babateen A, Shannon OM, Capper T, Ashor A, Stephan B, et al. Effects of inorganic nitrate and nitrite consumption on cognitive function and cerebral blood flow: a systematic review and meta-analysis of randomised clinical trials. Crit Rev Food Sci Nutr. 2019:59:2400-10.

35. Rosier BT, Buetas E, Moya-Gonzalvez EM, Artacho A, Mira A. Nitrate as a potential prebiotic for the oral microbiome. Sci Rep. 2020;10:12895.

36. Jockel-Schneider Y, Goßner SK, Petersen N, Stölzel P, Hägele F, Schweiggert RM, et al. Stimulation of the nitrate-nitrite-NO-metabolism by repeated lettuce juice consumption decreases gingival inflammation in periodontal recall patients: a randomized, double-blinded, placebo-controlled clinical trial. J Clin Periodontol. 2016:43:603-8.

37. Lansley KE, Winyard PG, Bailey SJ, Vanhatalo A, Wilkerson DP, Blackwell JR, et al. Acute dietary nitrate supplementation improves cycling time trial performance. Med Sci Sports Exerc. 2011;43:1125-31.

38. Lansley KE, Winyard PG, Fulford J, Vanhatalo A, Bailey SJ, Blackwell JR, et al. Dietary nitrate supplementation reduces the $\mathrm{O} 2$ cost of walking and running: a placebo-controlled study. J Appl Physiol. 2011;110:591-600.

39. Cermak NM, Gibala MJ, van Loon LJ, et al. Nitrate supplementation's improvement of 10-km time-trial performance in trained cyclists. Int I Sport Nutr Exerc Metab. 2012;22:64.

40. Porcelli S, Ramaglia M, Bellistri G, Pavei G, Pugliese L, Montorsi M, et al. Aerobic fitness affects the exercise performance responses to nitrate supplementation. Med Sci Sports Exerc. 2015;47(8):1643-51. https://doi.org/1 0.1249/MSS.00000000000000577. 
41. Shannon OM, Barlow MJ, Duckworth L, Williams E, Wort G, Woods D, et al. Dietary nitrate supplementation enhances short but not longer duration running time-trial performance. Eur J Appl Physiol. 2017;117:775-85.

42. Shannon OM, Duckworth L, Barlow MJ, Woods D, Lara J, Siervo M, et al. Dietary nitrate supplementation enhances high-intensity running performance in moderate normobaric hypoxia, independent of aerobic fitness. Nitric Oxide. 2016;59:63-70.

43. Wylie LJ, Bailey SJ, Kelly J, Blackwell JR, Vanhatalo A, Jones AM. Influence of beetroot juice supplementation on intermittent exercise performance. Eur J Appl Physiol. 2016;116:415-25.

44. Thompson C, Vanhatalo A, Jell H, Fulford J, Carter J, Nyman L, et al. Dietary nitrate supplementation improves sprint and high-intensity intermittent running performance. Nitric Oxide. 2016. https://doi.org/10.1016/j.niox.201 6.10 .006$.

45. Nyakayiru J, Jonvik KL, Trommelen J, Pinckaers PJM, Senden JM, van Loon LC, et al. Beetroot juice supplementation improves high-intensity intermittent type exercise performance in trained soccer players. Nutrients. 2017:9:314.

46. Mosher SL, Sparks SA, Williams EL, Bentley DJ, Mc Naughton LR. Ingestion of a nitric oxide enhancing supplement improves resistance exercise performance. J Strength Cond Res. 2016;30:3520-4.

47. de Oliveira GV, Morgado M, Conte-Junior CA, Alvares TS. Acute effect of dietary nitrate on forearm muscle oxygenation, blood volume and strength in older adults: a randomized clinical trial. PLoS One. 2017;12:e0188893.

48. Senefeld JW, Wiggins CC, Regimbal RJ, Dominelli PB, Baker SE, Joyner MJ. Ergogenic effect of nitrate supplementation: a systematic review and metaanalysis. Med Sci Sports Exerc. 2020;52:2250-61.

49. Jones AM. Influence of dietary nitrate on the physiological determinants of exercise performance: a critical review. Appl Physiol Nutr Metab. 2014;39: 1019-28.

50. Shannon O, McGawley K, Nybäck L, Duckworth L, Barlow MJ, Woods D, et al. 'Beet-ing' the mountain: a review of the physiological and performance effects of dietary nitrate supplementation at simulated and terrestrial altitude. Sports Med. 2017;47:2155-69.

51. Larsen FJ, Schiffer TA, Borniquel S, Sahlin K, Ekblom B, Lundberg JO, et al. Dietary inorganic nitrate improves mitochondrial efficiency in humans. Cell Metab. 2011;13:149-59.

52. Whitfield J, Ludzki A, Heigenhauser GJF, Senden JMG, Verdijk LB, van Loon LC, et al. Beetroot juice supplementation reduces whole body oxygen consumption but does not improve indices of mitochondrial efficiency in human skeletal muscle. J Physiol. 2016;594:421-35.

53. Bailey SJ, Fulford J, Vanhatalo A, Winyard PG, Blackwell JR, DiMenna FJ, et al. Dietary nitrate supplementation enhances muscle contractile efficiency during knee-extensor exercise in humans. J Appl Physiol. 2010;109:135-48.

54. Hernandez A, Schiffer TA, Ivarsson N, Cheng AJ, Bruton JD, Lundberg JO, et al. Dietary nitrate increases tetanic [Ca2+]i and contractile force in mouse fast-twitch muscle. J Physiol. 2012;590:3575-83.

55. Haider G, Folland JP. Nitrate supplementation enhances the contractile properties of human skeletal muscle. Med Sci Sports Exerc. 2014;46:2234-43.

56. Bailey SJ, Gandra PG, Jones AM, Hogan MC, Nogueira L. Incubation with sodium nitrite attenuates fatigue development in intact single mouse fibres at physiological PO2. J Physiol. 2019;597:5429-43.

57. Ferguson SK, Hirai DM, Copp SW, Holdsworth CT, Allen JD, Jones AM, et al. Impact of dietary nitrate supplementation via beetroot juice on exercising muscle vascular control in rats. J Physiol. 2013;591:547-57.

58. Ferguson SK, Holdsworth CT, Wright JL, Fees AJ, Allen JD, Jones AM, et al. Microvascular oxygen pressures in muscles comprised of different fiber types: impact of dietary nitrate supplementation. Nitric Oxide. 2015;48:38-43.

59. Bentley RF, Walsh JJ, Drouin PJ, Velickovic A, Kitner SJ, Fenuta AM, et al. Dietary nitrate restores compensatory vasodilation and exercise capacity in response to a compromise in oxygen delivery in the noncompensator phenotype. J Appl Physiol. 2017;123:594-605.

60. Craig JC, Broxterman RM, Smith JR, Allen JD, Barstow TJ. Effect of dietary nitrate supplementation on conduit artery blood flow, muscle oxygenation, and metabolic rate during handgrip exercise. J Appl Physiol (1985). 2018; 125:254-62.

61. Richards JC, Racine ML, Hearon CM, Kunkel M, Luckasen GJ, Larson DG, et al Acute ingestion of dietary nitrate increases muscle blood flow via local vasodilation during handgrip exercise in young adults. Physiol Rep. 2018;6. https://doi.org/10.14814/phy2.13572.
62. de Vries CJ, DeLorey DS. Effect of acute dietary nitrate supplementation on sympathetic vasoconstriction at rest and during exercise. J Appl Physiol. 2019;127:81-8.

63. Hughes WE, Kruse NT, Ueda K, Feider AJ, Hanada S, Bock JM, et al. Dietary nitrate does not acutely enhance skeletal muscle blood flow and vasodilation in the lower limbs of older adults during single-limb exercise. Eur J Appl Physiol. 2020;120:1357-69.

64. Wylie LJ, Kelly J, Bailey SJ, Blackwell JR, Skiba PF, Winyard PG, et al. Beetroot juice and exercise: pharmacodynamic and dose-response relationships. J Appl Physiol. 2013;115:325-36.

65. Flueck JL, Bogdanova A, Mettler S, Perret C. Is beetroot juice more effective than sodium nitrate?-the effects of equimolar nitrate dosages of nitrate-rich beetroot juice and sodium nitrate on oxygen consumption during exercise. Appl Physiol Nutr Metab. 2016;4:421-9.

66. Carlström M, Lundberg JO, Weitzberg E. Mechanisms underlying blood pressure reduction by dietary inorganic nitrate. Acta Physiol. 2018;224:e13080.

67. Blekkenhorst LC, Lewis JR, Prince RL, Devine A, Bondonno NP, Bondonno $C P$, et al. Nitrate-rich vegetables do not lower blood pressure in individuals with mildly elevated blood pressure: a 4-wk randomized controlled crossover trial. Am J Clin Nutr. 2018;107:894-908.

68. Sundqvist ML, Larsen FJ, Carlström M, Bottai M, Pernow J, Hellénius M-L, et al. A randomized clinical trial of the effects of leafy green vegetables and inorganic nitrate on blood pressure. Am J Clin Nutr. 2020;111:749-56.

69. Siervo M, Shannon O, Kandhari N, Prabhakar M, Fostier W, Köchl C, et al. Nitrate-rich beetroot juice reduces blood pressure in Tanzanian adults with elevated blood pressure: a double-blind randomized controlled feasibility trial. J Nutr. 2020;150:2460-8.

70. Mills CE, Govoni V, Faconti L, Casagrande M-L, Morant SV, Crickmore H, et al. A randomised, factorial trial to reduce arterial stiffness independently of blood pressure: proof of concept? The VaSera trial testing dietary nitrate and spironolactone. Br J Clin Pharmacol. 2020;86:891-902.

71. Kapil V, Khambata RS, Robertson A, Caulfield MJ, Ahluwalia A. Dietary nitrate provides sustained blood pressure lowering in hypertensive patients: a randomized, phase 2, double-blind, placebo-controlled study. Hypertension. 2015;65:320-7.

72. Thompson C, Wylie LJ, Blackwell JR, Fulford J, Black MI, Kelly J, et al. Influence of dietary nitrate supplementation on physiological and muscle metabolic adaptations to sprint interval training. J Appl Physiol. 2017;122(3): 642-52.

73. Rocha BS, Nunes C, Pereira C, Barbosa RM, Laranjinha J. A shortcut to wideranging biological actions of dietary polyphenols: modulation of the nitratenitrite-nitric oxide pathway in the gut. Food Funct. 2014;5:1646-52.

74. Clifford T, Howatson G, West DJ, Stevenson EJ. The potential benefits of red beetroot supplementation in health and disease. Nutrients. 2015;7:2801-22.

75. Tesoriere L, Allegra M, Butera D, Livrea MA. Absorption, excretion, and distribution of dietary antioxidant betalains in LDLs: potential health effects of betalains in humans. Am J Clin Nutr. 2004:80:941-5.

76. Martinez RM, Longhi-Balbinot DT, Zarpelon AC, Staurengo-Ferrari L, Baracat MM, Georgetti SR, et al. Anti-inflammatory activity of betalain-rich dye of Beta vulgaris: effect on edema, leukocyte recruitment, superoxide anion and cytokine production. Arch Pharm Res. 2015;38:494-504.

77. Nemzer BV, Pietrzkowski Z, Hunter JM, Robinson JL, Fink B. A Betalain-rich dietary supplement, but not PETN, increases vasodilation and nitric oxide: a comparative, single-dose, randomized, placebo-controlled, blinded, crossover pilot study. J Food Res. 2020;10:p26.

78. World Economic Forum. The global economic burden of noncommunicable diseases. Harvard School of Public Health. 2011.

79. Prince M, Wimo A, Ali G, Wu Y, Prina M. World Alzheimer report 2015: the global impact of dementia: an analysis of prevalence, incidence, cost and trends. London: Alzheimer's Disease International; 2015.

80. Ormesher L, Myers JE, Chmiel C, Wareing M, Greenwood SL, Tropea T, et al. Effects of dietary nitrate supplementation, from beetroot juice, on blood pressure in hypertensive pregnant women: a randomised, double-blind, placebo-controlled feasibility trial. Nitric Oxide. 2018;80:37-44.

81. Kandhari N, Prabhakar M, Shannon O, Fostier W, Koehl C, Rogathi J, et al. Feasibility and acceptability of a nutritional intervention testing the effects of nitrate-rich beetroot juice and folic acid on blood pressure in Tanzanian adults with elevated blood pressure. Int J Food Sci Nutr. 2020;72:195-207.

82. Choo E, Dando R. The impact of pregnancy on taste function. Chem Senses. 2017:42:279-86. 
83. Babateen AM, Rubele S, Shannon O, Okello E, Smith E, McMahon N, et al. Protocol and recruitment results from a 13-week randomized controlled trial comparing the effects of different doses of nitrate-rich beetroot juice on cognition, cerebral blood flow and peripheral vascular function in overweight and obese older people. Contemp Clin Trials Commun. 2020;18: 100571.

84. van der Wurff ISM, Meyer BJ, de Groot RHM. A review of recruitment, adherence and drop-out rates in omega-3 polyunsaturated fatty acid supplementation trials in children and adolescents. Nutrients. 2017;9(5):474.

85. Kemmler G, Hummer M, Widschwendter C, Fleischhacker WW. Dropout rates in placebo-controlled and active-control clinical trials of antipsychotic drugs: a meta-analysis. Arch Gen Psychiatry. 2005;62(12):1305-12.

86. McDonagh STJ, Wylie LJ, Webster JMA, Vanhatalo A, Jones AM. Influence of dietary nitrate food forms on nitrate metabolism and blood pressure in healthy normotensive adults. Nitric Oxide. 2018;72:66-74

87. Katan MB. Nitrate in foods: harmful or healthy? Am J Clin Nutr. 2009;90:11-2.

88. Shannon OM, Grisotto G, Babateen A, McGrattan A, Brandt K, Mathers JC, et al. Knowledge and beliefs about dietary inorganic nitrate among UKbased nutrition professionals: development and application of the KINDS online questionnaire. BMJ Open. 2019;9:e030719.

89. Siervo M, Lara J, Ogbonmwan I, Mathers JC. Inorganic nitrate and beetroot juice supplementation reduces blood pressure in adults: a systematic review and meta-analysis. J Nutr. 2013;143:818-26.

90. Faraoni D, Schaefer ST. Randomized controlled trials vs. observational studies: why not just live together? BMC Anesthesiol. 2016;16. https://doi. org/10.1186/s12871-016-0265-3.

91. Black N. Why we need observational studies to evaluate the effectiveness of health care. BMJ. 1996;312:1215-8.

92. Cowell OR, Mistry N, Deighton K, Matu J, Griffiths A, Minihane AM, et al. Effects of a Mediterranean diet on blood pressure: a systematic review and meta-analysis of randomized controlled trials and observational studies. J Hypertens. 2020;39:729-39.

93. Babateen AM, Fornelli G, Donini LM, Mathers JC, Siervo M. Assessment of dietary nitrate intake in humans: a systematic review. Am J Clin Nutr. 2018; 108:878-88.

94. McMahon N, Pavey T, Desbrow B, Leveritt M. Developing a nitrate, nitrite, and nitrosamine food and beverage composition database for use with a nitrate food frequency questionnaire: a systematic review. J Sci Med Sport. 2017;20:22.

95. de González MTN, Osburn WN, Hardin MD, Longnecker M, Garg HK, Bryan NS, et al. A survey of nitrate and nitrite concentrations in conventional and organic-labeled raw vegetables at retail. J Food Sci. 2015;80:C942-9.

96. Blekkenhorst LC, Prince RL, Ward NC, Croft KD, Lewis JR, Devine A, et al. Development of a reference database for assessing dietary nitrate in vegetables. Mol Nutr Food Res. 2017;61. https://onlinelibrary.wiley.com/doi/a bs/10.1002/mnfr.201600982.

97. Bahadoran Z, Ghasemi A, Mirmiran P, Mehrabi Y, Azizi F, Hadaegh F. Estimation and validation of dietary nitrate and nitrite intake in iranian population. Iran J Public Health. 2019;48:162-70.

98. Pereira LCR, Shannon OM, Mazidi M, Babateen AM, Ashor AW, Stephan $\mathrm{BCM}$, et al. Relationship between urinary nitrate concentrations and cognitive function in older adults: findings from the NHANES survey. Int J Food Sci Nutr. 2021:4:1-11.

99. Bahadoran Z, Mirmiran P, Ghasemi A, Carlström M, Azizi F, Hadaegh F. Vitamin C intake modify the impact of dietary nitrite on the incidence of type 2 diabetes: a 6-year follow-up in Tehran lipid and glucose study. Nitric Oxide. 2017:62:24-31.

100. Kang JH, Willett WC, Rosner BA, Buys E, Wiggs JL, Pasquale LR. Association of dietary nitrate intake with primary open-angle glaucoma: a prospective analysis from the nurses' health study and health professionals follow-up study. JAMA Ophthalmol. 2016;134:294-303.

101. Mirmiran P, Bahadoran Z, Golzarand M, Asghari G, Azizi F. Consumption of nitrate containing vegetables and the risk of chronic kidney disease: Tehran lipid and glucose study. Ren Fail. 2016;38:937-44.

102. Blekkenhorst LC, Bondonno CP, Lewis JR, Devine A, Woodman RJ, Croft KD, et al. Association of dietary nitrate with atherosclerotic vascular disease mortality: a prospective cohort study of older adult women. Am J Clin Nutr. 2017;106(1):207-16.

103. Bondonno CP, Blekkenhorst $L C$, Prince $R L$, Ivey $K L$, Lewis JR, Amanda D, et al. Association of vegetable nitrate intake with carotid atherosclerosis and ischemic cerebrovascular disease in older women. Stroke. 2017:48:1724-9.
104. Gumanova NG, Deev AD, Klimushina MV, Kots AY, Shalnova SA. Serum nitrate and nitrite are associated with the prevalence of various chronic diseases except cancer. Int Angiol. 2017;36:160-6.

105. Kuhnle GG, Luben R, Khaw K-T, Feelisch M. Sulfate, nitrate and blood pressure - an EPIC interaction between sulfur and nitrogen. Pharmacol Res. 2017:122:127-9.

106. Maas R, Xanthakis V, Göen T, Müller J, Schwedhelm E, Böger RH, et al. Plasma nitrate and incidence of cardiovascular disease and all-cause mortality in the community: the Framingham offspring study. J Am Heart Assoc. 2017;6:e006224

107. Smallwood MJ, Ble A, Melzer D, Winyard PG, Benjamin N, Shore AC, et al. Relationship between urinary nitrate excretion and blood pressure in the InChianti cohort. Am J Hypertens. 2017;30:707-12.

108. Liu AH, Bondonno CP, Russell J, Flood VM, Lewis JR, Croft KD, et al. Relationship of dietary nitrate intake from vegetables with cardiovascular disease mortality: a prospective study in a cohort of older Australians. Eur J Nutr. 2019;58(7):2741-53.

109. Mendy A. Association of urinary nitrate with lower prevalence of hypertension and stroke and with reduced risk of cardiovascular mortality. Circulation. 2018;137:2295-7.

110. Jackson JK, Patterson AJ, MacDonald-Wicks LK, Forder PM, Blekkenhorst LC, Bondonno $C P$, et al. Vegetable nitrate intakes are associated with reduced self-reported cardiovascular-related complications within a representative sample of middle-aged Australian women, prospectively followed up for 15 years. Nutrients. 2019;11. https://www.mdpi.com/2072-6643/11/2/240.

111. Jackson JK, Zong G, MacDonald-Wicks LK, Patterson AJ, Willett WC, Rimm $\mathrm{EB}$, et al. Dietary nitrate consumption and risk of CHD in women from the nurses' health study. Br J Nutr. 2019;121:831-8.

112. Sim M, Lewis JR, Blekkenhorst LC, Bondonno CP, Devine A, Zhu K, et al. Dietary nitrate intake is associated with muscle function in older women. J Cachexia Sarcopenia Muscle. 2019;10:601-10.

113. Riddell A, Kirkwood J, Smallwood M, Winyard P, Knight B, Romanczuk L, et al. Urinary nitrate concentration as a marker for kidney transplant rejection. BMC Nephrol. 2020;21:441.

114. Wu Z, Tian T, Ma W, Gao W, Song N. Higher urinary nitrate was associated with lower prevalence of congestive heart failure: results from NHANES. BMC Cardiovasc Disord. 2020;20:498.

115. Amrita A, Mark G, Coleman Gary D, Norman H, George H, Kim-Shapiro Daniel B, et al. Dietary nitrate and the epidemiology of cardiovascular disease: Report from a National Heart, Lung, and Blood Institute Workshop. J Am Heart Assoc. 2016;5:e003402.

116. Song $P$, Wu L, Guan W. Dietary nitrates, nitrites, and nitrosamines intake and the risk of gastric cancer: a meta-analysis. Nutrients. 2015;7:9872-95.

117. Xie L, Mo M, Jia H-X, Liang F, Yuan J, Zhu J. Association between dietary nitrate and nitrite intake and sitespecific cancer risk: evidence from observational studies. Oncotarget. 2016;7:56915-32.

118. Bourdillon N, Fan J-L, Uva B, Müller H, Meyer P, Kayser B. Effect of oral nitrate supplementation on pulmonary hemodynamics during exercise and time trial performance in normoxia and hypoxia: a randomized controlled trial. Front Physiol. 2015;6. https://doi.org/10.3389/fphys.2015.00288.

119. James PE, Willis GR, Allen JD, Winyard PG, Jones AM. Nitrate pharmacokinetics: taking note of the difference. Nitric Oxide. 2015. https:// doi.org/10.1016/j.niox.2015.04.006.

120. Atkinson G, Batterham AM. True and false interindividual differences in the physiological response to an intervention. Exp Physiol. 2015;100: 577-88.

121. Liddle L, Burleigh MC, Monaghan C, Muggeridge DJ, Sculthorpe N, Pedlar $\mathrm{CR}$, et al. Variability in nitrate-reducing oral bacteria and nitric oxide metabolites in biological fluids following dietary nitrate administration: an assessment of the critical difference. Nitric Oxide. 2019:83:1-10.

122. Betts JA, Gonzalez JT. Personalised nutrition: what makes you so special? Nutr Bull. 2016:41:353-9.

123. Deighton K, King JA, Stensel DJ, Jones B. Expanding the investigation of meaningful effects in physiology research. Future Sci OA. 2017:3(3):FSO218.

124. Ahmed KA, Kim K, Ricart K, Van Der Pol W, Qi X, Bamman MM, et al. Potential role for age as a modulator of oral nitrate reductase activity. Nitric Oxide. 2021;108:1-7.

125. Stanaway L, Rutherfurd-Markwick K, Page R, Wong M, Jirangrat W, Teh KH, et al. Acute supplementation with nitrate-rich beetroot juice causes a greater increase in plasma nitrite and reduction in blood pressure of older compared to younger adults. Nutrients. 2019;11:1683. 
126. Ashworth A, Mitchell K, Blackwell JR, Vanhatalo A, Jones AM. High-nitrate vegetable diet increases plasma nitrate and nitrite concentrations and reduces blood pressure in healthy women. Public Health Nutr. 2015;18: 2669-78.

127. Hobbs DA, George TW, Lovegrove JA. Differential effect of beetroot bread on postprandial DBP according to Glu298Asp polymorphism in the eNOS gene: a pilot study. J Hum Hypertens. 2014;28:726-30.

128. Bailey SJ, Blackwell JR, Wylie L, Holland T, Winyard PG, Jones AM, et al. Nitric Oxide. 2016;61:29-37.

129. Alzahrani HS, Jackson KG, Hobbs DA, Lovegrove JA. The role of dietary nitrate and the oral microbiome on blood pressure and vascular tone. Nutr Res Rev. 2020;7:1-18.

130. Dewhurst-Trigg R, Yeates T, Blackwell JR, Thompson C, Linoby A, Morgan PT, et al. Lowering of blood pressure after nitrate-rich vegetable consumption is abolished with the co-ingestion of thiocyanate-rich vegetables in healthy normotensive males. Nitric Oxide. 2018;74:39-46.

131. Jones AM. Dietary nitrate supplementation and exercise performance. Sports Med. 2014;44:35-45.

132. Wilkerson DP, Hayward GM, Bailey SJ, Vanhatalo A, Blackwell JR, Jones AM. Influence of acute dietary nitrate supplementation on 50 mile time trial performance in well-trained cyclists. Eur J Appl Physiol. 2012;112:4127-34.

133. Peacock O, TjøNna AE, James P, WisløFf U, Welde B, BöHlke N, et al. Dietary nitrate does not enhance running performance in elite cross-country skiers. Med Sci Sports Exerc. 2012;44:2213-9.

134. Nybäck L, Glännerud C, Larsson G, Weitzberg E, Shannon OM, McGawley K Physiological and performance effects of nitrate supplementation during roller-skiing in normoxia and normobaric hypoxia. Nitric Oxide. 2017;70:1-8.

135. Boorsma RK, Whitfield J, Spriet LL. Beetroot juice supplementation does not improve performance in elite 1500-m runners. Med Sci Sports Exerc. 2014; 46:2326-34.

136. Jonvik KL, Nyakayiru J, van Loon LJC, Verdijk LB. Can elite athletes benefit from dietary nitrate supplementation? J Appl Physiol. 2015;119:759-61.

137. Gollnick PD, Matoba H. The muscle fiber composition of skeletal muscle as a predictor of athletic success. An overview. Am J Sports Med. 1984;12:212-7.

138. Tesch PA, Karlsson J. Muscle fiber types and size in trained and untrained muscles of elite athletes. J Appl Physiol. 1985;59:1716-20.

139. Hoon MW, Jones AM, Johnson NA, Blackwell JR, Broad EM, Lundy B, et al. The effect of variable doses of inorganic nitrate-rich beetroot juice on simulated 2,000 $\mathrm{m}$ rowing performance in trained athletes. Int j sports physiol perform. 2014;9:615-20.

140. Peeling P, Cox GR, Bullock N, Burke LM. Beetroot juice improves on-water $500 \mathrm{~m}$ time-trial performance, and laboratory-based paddling economy in national and international-level kayak athletes. Int J Sport Nutr Exerc Metab. 2014;25:278-84

141. Rokkedal-Lausch T, Franch J, Poulsen MK, Thomsen LP, Weitzberg E, Kamavuako EN, et al. Chronic high-dose beetroot juice supplementation improves time trial performance of well-trained cyclists in normoxia and hypoxia. Nitric Oxide. 2019;85:44-52.

142. Wickham KA, Spriet LL. No longer beeting around the bush: a review of potential sex differences with dietary nitrate supplementation 1. Appl Physiol Nutr Metab. 2019:44:915-24.

143. Kapil V, Rathod KS, Khambata RS, Bahra M, Velmurugan S, Purba A, et al. Sex differences in the nitrate-nitrite-NO pathway: role of oral nitrate-reducing bacteria. Free Radic Biol Med. 2018;126:113-21.

144. Coles LT, Clifton PM. Effect of beetroot juice on lowering blood pressure in free-living, disease-free adults: a randomized, placebo-controlled trial. Nutr J. 2012;11:106

145. Forte P, Kneale BJ, Milne E, Chowienczyk PJ, Johnston A, Benjamin N, et al. Evidence for a difference in nitric oxide biosynthesis between healthy women and men. Hypertension. 1998;32:730-4.

146. Azzam N, Zafrir B, Fares F, Smith Y, Salman N, Nevzorov R, et al. Endothelial nitric oxide synthase polymorphism and prognosis in systolic heart failure patients. Nitric Oxide. 2015;47:91-6.

147. Lembo G, De Luca N, Battagli C, lovino G, Aretini A, Musicco M, et al. A common variant of endothelial nitric oxide synthase (Glu298Asp) is an independent risk factor for carotid atherosclerosis. Stroke. 2001;32:735-40.

148. Tian G-X, Zeng X-T, Wang X-B, Zhang L, Zhang W, Wei W-L. Association between the endothelial nitric oxide synthase gene Glu298Asp polymorphism and coronary heart disease: a meta-analysis of 39 casecontrol studies. Mol Med Rep. 2013:7:1310-8.
149. Jiménez-Morales Al, Ruano J, Delgado-Lista J, Fernandez JM, Camargo A, López-Segura F, et al. NOS3 Glu298Asp polymorphism interacts with virgin olive oil phenols to determine the postprandial endothelial function in patients with the metabolic syndrome. J Clin Endocrinol Metab. 2011;96: E1694-702.

150. Naseem KM. The role of nitric oxide in cardiovascular diseases. Mol Asp Med. 2005;26:33-65.

151. Siervo M, Scialò F, Shannon OM, Stephan BCM, Ashor AW. Does dietary nitrate say NO to cardiovascular ageing? Current evidence and implications for research. Proc Nutr Soc. 2018;77:112-23.

152. Woessner MN, Levinger I, Allen JD, Mcllvenna LC, Neil C. The effect of dietary inorganic nitrate supplementation on cardiac function during submaximal exercise in men with heart failure with reduced ejection fraction (HFrEF): a pilot study. Nutrients. 2020;12:2132.

153. Zamani $P$, Rawat D, Shiva-Kumar P, Geraci S, Bhuva R, Konda $P$, et al. The effect of inorganic nitrate on exercise capacity in heart failure with preserved ejection fraction. Circulation. 2015;131:371-80.

154. Zamani P, Tan V, Haideliza S-C, Melissa B, Brandimarto Jeffrey A, Lien T, et al. Pharmacokinetics and pharmacodynamics of inorganic nitrate in heart failure with preserved ejection fraction. Cir Res. 2017;120:1151-61.

155. Chirinos JA, Londono-Hoyos F, Zamani P, Beraun M, Haines P, Vasim I, et al. Effects of organic and inorganic nitrate on aortic and carotid haemodynamics in heart failure with preserved ejection fraction. Eur J Heart Fail. 2017;19:1507-15.

156. Hirai DM, Zelt JT, Jones JH, Castanhas LG, Bentley RF, Earle W, et al. Dietary nitrate supplementation and exercise tolerance in patients with heart failure with reduced ejection fraction. Am J Physiol Regul Integr Comp Physiol. 2016:312:R13-22.

157. Shaltout HA, Eggebeen J, Marsh AP, Brubaker PH, Laurienti PJ, Burdette JH, et al. Effects of supervised exercise and dietary nitrate in older adults with controlled hypertension and/or heart failure with preserved ejection fraction. Nitric Oxide. 2017. https://doi.org/10.1016/j.niox.2017.05.005.

158. Tsuge K, Kataoka M, Seto Y. Cyanide and thiocyanate levels in blood and saliva of healthy adult volunteers. J Health Sci. 2000:46:343-50.

159. Edwards DA, Fletcher K, Rowlands EN. Antagonism between perchlorate, iodide, thiocyanate and nitrate for secretion in human saliva. Analogy with the iodide trap of the thyroid. Lancet. 1954;263:498-9.

160. Jonvik KL, Nyakayiru J, Van Dijk J-W, Wardenaar FC, Van Loon LJC, Verdijk LB. Habitual dietary nitrate intake in highly trained athletes. Int J Sport Nutr Exerc Metab. 2016;27:148-57.

161. Angelino D, Dosz EB, Sun J, Hoeflinger JL, Van Tassell ML, Chen P, et al. Myrosinase-dependent and -independent formation and control of isothiocyanate products of glucosinolate hydrolysis. Front Plant Sci. 2015;6: 831.

162. Ashby MT. Inorganic chemistry of defensive peroxidases in the human oral cavity. J Dent Res. 2008;87:900-14.

163. Hughan KS, Wendell SG, Delmastro-Greenwood M, Helbling N, Corey C, Bellavia $L$, et al. Conjugated linoleic acid modulates clinical responses to oral nitrite and nitrate. Hypertension. 2017:7:634-44.

164. Bailey SJ, Blackwell JR, Wylie LJ, Emery A, Taylor E, Winyard PG, et al. Influence of iodide ingestion on nitrate metabolism and blood pressure following short-term dietary nitrate supplementation in healthy normotensive adults. Nitric Oxide. 2017;63:13-20.

165. Fiore E, Tonacchera M, Vitti P. Influence of iodization programmes on the epidemiology of nodular goitre. Best Pract Res Clin Endocrinol Metab. 2014; 28:577-88.

166. Rossman MJ, Gioscia-Ryan RA, Santos-Parker JR, Ziemba BP, Lubieniecki KL, Johnson LC, et al. Inorganic nitrite supplementation improves endothelial function with aging. Hypertension. 2021;77:1212-22.

167. Mirvish SS. Blocking the formation of N-nitroso compounds with ascorbic acid in vitro and in vivo. Ann N Y Acad Sci. 1975;258:175-80.

168. Doel JJ, Benjamin N, Hector MP, Rogers M, Allaker RP. Evaluation of bacterial nitrate reduction in the human oral cavity. Eur J Oral Sci. 2005;113:14-9.

169. Kilian M, Chapple ILC, Hannig M, Marsh PD, Meuric V, Pedersen AML, et al. The oral microbiome - an update for oral healthcare professionals. Br Dent J. 2016;221:657-66.

170. Hyde ER, Andrade F, Vaksman Z, Parthasarathy K, Jiang H, Parthasarathy DK, et al. Metagenomic analysis of nitrate-reducing bacteria in the oral cavity: implications for nitric oxide homeostasis. PLoS One. 2014;9:e88645.

171. Burleigh MC, Liddle L, Monaghan C, Muggeridge DJ, Sculthorpe N, Butcher $J P$, et al. Salivary nitrite production is elevated in individuals with a higher 
abundance of oral nitrate-reducing bacteria. Free Radic Biol Med. 2018;120 80-8.

172. Bescos R, Ashworth A, Cutler C, Brookes ZL, Belfield L, Rodiles A, et al. Effects of chlorhexidine mouthwash on the oral microbiome. Sci Rep. 2020; 10:5254

173. Govoni M, Jansson EA, Weitzberg E, Lundberg JO. The increase in plasma nitrite after a dietary nitrate load is markedly attenuated by an antibacterial mouthwash. Nitric Oxide. 2008;19:333-7.

174. Bondonno CP, Liu AH, Croft KD, Considine MJ, Puddey IB, Woodman RJ, et al. Antibacterial mouthwash blunts oral nitrate reduction and increases blood pressure in treated hypertensive men and women. Am J Hypertens. 2015;28:572-5

175. Woessner M, Smoliga JM, Tarzia B, Stabler T, Van Bruggen M, Allen JD. A stepwise reduction in plasma and salivary nitrite with increasing strengths of mouthwash following a dietary nitrate load. Nitric Oxide. 2016;54:1-7.

176. McDonagh STJ, Wylie LJ, Winyard PG, Vanhatalo A, Jones AM. The effects of chronic nitrate supplementation and the use of strong and weak antibacterial agents on plasma nitrite concentration and exercise elood pressure. Int J Sports Med. 2015:36:1177-85.

177. Jansson L, Lavstedt S, Frithiof L. Relationship between oral health and mortality rate. J Clin Periodontol. 2002;29:1029-34.

178. Hall MW, Singh N, Ng KF, Lam DK, Goldberg MB, Tenenbaum HC, et al. Inter-personal diversity and temporal dynamics of dental, tongue, and salivary microbiota in the healthy oral cavity. NPJ BiofilmsMicrobiomes. 2017:3:1-7.

179. Affoo RH, Foley N, Garrick R, Siqueira WL, Martin RE. Meta-analysis of salivary flow rates in young and older adults. J Am Geriatr Soc. 2015;63:2142-51.

180. Percival RS, Challacombe SJ, Marsh PD. Age-related microbiological changes in the salivary and plaque microflora of healthy adults. J Med Microbiol. 1991;35:5-11.

181. Xu X, He J, Xue J, Wang Y, Li K, Zhang K, et al. Oral cavity contains distinct niches with dynamic microbial communities. Environ Microbiol. 2015;17: 699-710.

182. Vanhatalo A, Blackwell JR, L'Heureux JE, Williams DW, Smith A, van der Giezen M, et al. Nitrate-responsive oral microbiome modulates nitric oxide homeostasis and blood pressure in humans. Free Radic Biol Med. 2018;124: $21-30$.

183. Kho H-S, Lee S-W, Chung S-C, Kim Y-K. Oral manifestations and salivary flow rate, $\mathrm{pH}$, and buffer capacity in patients with end-stage renal disease undergoing hemodialysis. Oral Surg Oral Med Oral Path Oral Radiol Endod. 1999;88:316-9.

184. Schmidt RJ, Yokota S, Tracy TS, Sorkin MI, Baylis C. Nitric oxide production is low in end-stage renal disease patients on peritoneal dialysis. Am J Phys. 1999;276:F794-7.

185. Burleigh M, Liddle L, Muggeridge DJ, Monaghan C, Sculthorpe N, Butcher J, et al. Dietary nitrate supplementation alters the oral microbiome but does not improve the vascular responses to an acute nitrate dose. Nitric Oxide. 2019;89:54-63.

186. Belstrøm D, Constancias F, Liu Y, Yang L, Drautz-Moses DI, Schuster SC, et al. Metagenomic and metatranscriptomic analysis of saliva reveals diseaseassociated microbiota in patients with periodontitis and dental caries. NPJ Biofilms Microbiomes. 2017;3:23.

187. Jeong H, Arif B, Caetano-Anollés G, Kim KM, Nasir A. Horizontal gene transfer in human-associated microorganisms inferred by phylogenetic reconstruction and reconciliation. Sci Rep. 2019:9:5953.

188. Doel JJ, Hector MP, Amirtham CV, Al-Anzan LA, Benjamin N, Allaker RP. Protective effect of salivary nitrate and microbial nitrate reductase activity against caries. Eur J Oral Sci. 2004;112:424-8.

189. Burleigh MC, Sculthorpe N, Henriquez FL, Easton C. Nitrate-rich beetroot juice offsets salivary acidity following carbohydrate ingestion before and after endurance exercise in healthy male runners. PLoS One. 2020;15: e0243755.

190. Statement on possible public health risks for infants and young children from the presence of nitrates in leafy vegetables. EFSA Journal. 2010.

191. IARC Working Group on the Evaluation of Carcinogenic Risks to Humans. Ingested Nitrate and Nitrite, and Cyanobacterial Peptide Toxins. IARC Monographs on the Evaluation of Carcinogenic Risks to Humans. 2010

192. Comly HH. Cyanosis in infants caused by nitrates in well water. JAMA. 1945; 129:112-6.

193. Fewtrell L. Drinking-water nitrate, methemoglobinemia, and global burden of disease: a discussion. Environ Health Perspect. 2004;112(14):1371-4.
194. Liu AH, Bondonno CP, Russell J, Flood VM, Lewis JR, Croft KD, et al. Relationship of dietary nitrate intake from vegetables with cardiovascular disease mortality: a prospective study in a cohort of older Australians. Eur J Nutr. 2019:58:2741-53.

195. Shannon OM, Ashor AW, Scialo F, Saretzki G, Martin-Ruiz C, Lara J, et al. Mediterranean diet and the hallmarks of ageing. Eur J Clin Nutr. 2021. https://doi.org/10.1038/s41430-020-00841-x.

196. Sofi F, Macchi C, Abbate R, Gensini GF, Casini A. Mediterranean diet and health status: an updated meta-analysis and a proposal for a literaturebased adherence score. Public Health Nutr. 2014;17:2769-82.

197. Carter P, Gray LJ, Troughton J, Khunti K, Davies MJ. Fruit and vegetable intake and incidence of type 2 diabetes mellitus: systematic review and meta-analysis. BMJ. 2010;341:C4229.

198. Hirayama F, Lee AH, Binns CW, Zhao Y, Hiramatsu T, Tanikawa Y, et al. Do vegetables and fruits reduce the risk of chronic obstructive pulmonary disease? A case-control study in Japan. Prev Med. 2009;49:184-9.

199. Shannon OM, Stephan BCM, Minihane A-M, Mathers JC, Siervo M. Nitric oxide boosting effects of the Mediterranean diet: a potential mechanism of action. J Gerontol A Biol Sci Med Sci. 2018;73:902-4.

200. Shannon OM, Mendes I, Köchl C, Mazidi M, Ashor AW, Rubele S, et al. Mediterranean diet increases endothelial function in adults: a systematic review and meta-analysis of randomized controlled trials. J Nutr. 2020; 150(5)::1151-9.

201. Shannon OM, Stephan BCM, Granic A, Lentjes M, Hayat S, Mulligan A, et al. Mediterranean diet adherence and cognitive function in older UK adults: the European prospective investigation into Cancer and nutrition-Norfolk (EPIC-Norfolk) study. Am J Clin Nutr. 2019;110:938-48.

202. Stevenson EJ, Shannon OM, Minihane AM, Adamson A, Burns A, Hill T, et al. NuBrain: UK consortium for optimal nutrition for healthy brain ageing. Nutr Bull. 2020:45:223-9.

203. Carlström M, Liu M, Yang T, Zollbrecht C, Huang L, Peleli M, et al. Cross-talk between nitrate-nitrite-NO and NO synthase pathways in control of vascular NO homeostasis. Antioxid Redox Signal. 2015;23:295-306.

204. Hezel MP, Liu M, Schiffer TA, Larsen FJ, Checa A, Wheelock CE, et al. Effects of long-term dietary nitrate supplementation in mice. Redox Biol. 2015;5: 234-42.

205. Lundberg JO, Carlström M, Weitzberg E. Metabolic effects of dietary nitrate in health and disease. Cell Metab. 2018;28:9-22.

206. Wootton-Beard PC, Ryan L. A beetroot juice shot is a significant and convenient source of bioaccessible antioxidants. J Funct Foods. 2011;3:329-34.

207. EFSA (European Food Safety Authority). Annual report of the emerging risks exchange network European Food Safety Authority. EFSA Supporting publication. 2016.

208. Mitchell T, Kumar P, Reddy T, Wood KD, Knight J, Assimos DG, et al. Dietary oxalate and kidney stone formation. Am J Physiol Renal Physiol. 2019;316: F409-13.

209. Hanson CF, Frankos VH, Thompson WO. Bioavailability of oxalic acid from spinach, sugar beet fibre and a solution of sodium oxalate consumed by female volunteers. Food Chem Toxicol. 1989;27:181-4.

210. Noonan SC. Oxalate content of foods and its effect on humans. Asia Pac $J$ Clin Nutr. 1999:8:64-74.

211. Siener R, Seidler A, Voss S, Hesse A. The oxalate content of fruit and vegetable juices, nectars and drinks. J Food Comp Anal. 2016;45:108-12.

212. Taylor EN, Curhan GC. Oxalate intake and the risk for nephrolithiasis. J Am Soc Nephrol. 2007:18:2198-204.

213. Maddahi N, Aghamir SMK, Moddaresi SS, Mirzaei K, Alizadeh S, Yekaninejad MS. The association of dietary approaches to stop hypertension-style diet with urinary risk factors of kidney stones formation in men with nephrolithiasis. Clin Nutr ESPEN. 2020:39:173-9.

\section{Publisher's Note}

Springer Nature remains neutral with regard to jurisdictional claims in published maps and institutional affiliations. 